\title{
Eating in silence: isotopic approaches to nuns' diet at the convent of Santa Catalina de Siena (Belmonte, Spain) from the sixteenth to the twentieth century
}

\author{
Natasa Sarkic ${ }^{1}$ Jesús Herrerín López ${ }^{1}$ - Olalla López-Costas ${ }^{2,3,4} \cdot$ Aurora Grandal-d'Anglade $^{5}$
}

Received: 3 April 2018 / Accepted: 19 September 2018 /Published online: 8 November 2018

(C) The Author(s) 2018

\begin{abstract}
Advances in geochemical and physical anthropological studies have provided new tools to reconstruct ancient lifestyles, especially of those minorities not commonly mentioned in historical texts. In comparison to males, little is known about everyday life in female monastic communities, and how it has changed over time. In this paper, we present a paleodietary $\left(\delta^{13} \mathrm{C}\right.$ and $\delta^{15} \mathrm{~N}$ in bone collagen) study of human $(n=58)$ and animal $(n=13)$ remains recovered from the former Convent of Santa Catalina de Siena in Belmonte (Cuenca, central Spain). Two funerary areas used by Dominican nuns were sampled: one dated to the sixteenth $(n=34)$ and the seventeenth $(n=15)$ centuries, and the other dated in the nineteenth and twentieth $(n=9)$ centuries. The isotopic values for sheep $(n=7)$ suggest the animals consumed at the convent came from diverse ecosystems or were raised under a range of management strategies. The human samples reflect a terrestrial diet, and those from the nineteenth to twentieth century, in some cases, reveal the presence of $\mathrm{C}_{4}$ plants (millet, corn or sugar cane). Due to their religious practice, the consumption of terrestrial animal protein was restricted, and although they were allowed to eat fish, the isotopic signatures show little evidence of this. The individuals from the sixteenth and seventeenth century show a continuous shift in $\delta^{15} \mathrm{~N}(9.7-12.7 \%$ ), with few significant differences in relation to the period, age, or pathologies (osteoporosis, periostitis, and brucellosis). The nineteenth- to twentieth-century samples can be divided into two groups: (a) one that fits the trend of previous centuries, albeit with a higher $\delta^{15} \mathrm{~N}$, possibly related to extensive access to animal protein; and (b) a second group with elevated $\delta^{13} \mathrm{C}$ values (up to $-15.7 \%$ ). Different customs in the assumed homogeneous monastic life are discussed as possible sources of isotopic variation, including access to luxury products such as animal protein or sugar, or the practice of periods of food abstinence, which were especially popular with these communities, according to historical records.
\end{abstract}

Keywords Isotopic analysis in collagen $\cdot \delta^{13} \mathrm{C} \cdot \delta^{15} \mathrm{~N} \cdot$ Paleodiet $\cdot$ Paleopathology $\cdot$ Modern period $\cdot$ Female monastic population

\section{Abbreviations}

POB MON 1 The necropolis located in the cloister of the Convent of Santa Catalina de Siena, Belmonte (Spain), from the sixteenth to seventeenth centuries
POB MON 2 The necropolis located in the choir of the Convent of Santa Catalina de Siena, Belmonte (Spain), from the nineteenth to twentieth centuries
Natasa Sarkic

nsarkic@gmail.com

Jesús Herrerín López

jesus.herrerin@uam.es

Olalla López-Costas

olalla.lopez@usc.es; olallalc@gmail.com

Aurora Grandal-d'Anglade

aurora.grandal@udc.es
1 Dpto. Biología. Facultad de Biología, Universidad Autónoma de Madrid, Campus de Cantoblanco, C/ Darwin, 2, 28049 Madrid, Spain

2 Group Earth System Science (GI-1553), Universidade de Santiago de Compostela, 15782 Santiago de Compostela, Spain

3 Archaeological Research Laboratory, Stockholm University, Sweden, Universitetsvägen 10, 11418 Stockholm, Sweden

4 Laboratory of Anthropology, University of Granada, Spain, Av. del Hospicio, s/n, 18010 Granada, Spain

5 Instituto Universitario de Xeoloxía, Universidade da Coruña, ESCI, Campus de Elviña s/n, 15071 A Coruña, Spain 


\section{Introduction}

The study of diet is an essential component of the reconstruction of past populations. The need for food has driven many integral components of human society, such as settlement locations and distributions, population sizes, social organisation, and the development of technology (Bonsall et al. 1997). Progress in geophysical studies has allowed the reconstruction of the paleodiet, especially that of populations that are not frequently mentioned in historical texts, such as nuns. Although female monasteries undoubtedly played an important role as centres of spirituality and education for women, little is known about the everyday lives of their inhabitants, and how it changed over time.

The eighteenth century in Spain brought progressive economic and technological development (Floristán 2011), as well as the decline in mortality due to improvements in nutrition (the influx of new foods), health, hygiene, and the treatment of diseases (Santonja 1999). Despite its importance, few osteoarchaeological and isotopic studies have addressed collections from this period and changes in health and diet, compared to previous centuries. The skeletal remains that are the object of this study proceed from the same monastery, but from a range of epochs (the sixteenth to seventeenth and the nineteenth to twentieth centuries); this offers a unique opportunity to understand the effect of the transition to industrialisation on a population that almost entirely preserved its way of life over the centuries.

Nuns also offer an advantage, compared to other cohorts: their relatively homogeneous way of life allows an exploration of the effect of individual physiological characteristics in isotopic signals. Unlike most secular populations, the diet followed by monastic populations does not reflect social status, in that their nutrition is dictated by strict religious rules, including abstinence and fasting. Fasting in Christianity entails avoiding meat, dairy products, and eggs, for approximately a half of the year, and on every Wednesday and Friday throughout the rest of the year. Fish and seafood (such as shrimps, squid, cuttlefish, octopus, lobsters, crabs, snails, etc.) are allowed on all fasting days throughout the year. However, even for non-fasting days, it was suggested that reduced amounts of food, and especially meat, be consumed, "so far as your health permits" ("Constitutions of the Nuns of the Order of Preachers" 2015). The only habitants of a monastery excluded from the obligation to fast were the sick, children under 14, and those undergoing leech therapy ("Constitutions of the Nuns of the Order of Preachers" 2015). Refraining from the consumption of meat and food of animal origin during fasting periods seems to have been of great importance for religious communities; the Constitutions stresses in several places that sick nuns need to return to their previous eating habits, after recovering from a period of ill health.

\section{Historical context}

The ancient fortress of the Infante Don Juan Manuel at Belmonte (Spain) was converted into the Dominican Convent of Santa Catalina de Siena in the sixteenth century ("Libro Becerro del Monasterio de Nuestra Señora de la Mejorada, de La Orden de San Jerónimo, de la villa de Olmedo" 1760), and it remained in use for this purpose until 1960, when it was abandoned. Three necropolises have been excavated inside the fortress. One was located in the cloister area (POB MON 1) and is considered the earliest, dating from the sixteenth to the seventeenth century. A total of 27 tombs and at least 85 individuals were discovered there, all of whom were members of the monastic population. The second funerary area was located in the choir area (POB MON 2) and dated from the nineteenth to the twentieth century, containing 31 individuals in 45 tombs (some of the tombs were empty), all of whom were nuns. The third necropolis was discovered in the church floor, and was reserved for the secular population (Fig. 1).

In total, the convent together with the outdoor areas that belonged to it had a surface of more than $7000 \mathrm{~m}^{2}$. On the ground floor there was a choir, antechoir, church, kitchens, refectory, nursing station, rooms for wine and olive oil production, a storeroom, and warehouses, while on the upper floor there were cells for nuns, rooms for work, a library, and some other rooms whose use is still undetermined. The outdoor area included a garden with a well and a mill. In the eighteenth century, stables were added to the main building (Caballero and Sánchez 2013). Apart from numerous glass, metal, stone, and ceramic remains, traces of fauna including the bones of hens, lambs, pigs, and fish (both freshwater and saltwater) and eggshells were also noted in the burial area. Archaeobotanical data were not available for this study because no flotation sampling has yet been carried out.

\section{Stable isotopes and diet}

Stable isotope analysis of bone or dentine collagen has been used for the dietary reconstruction of ancient human populations by analysing the ratios of carbon $\left({ }^{13} \mathrm{C} /{ }^{12} \mathrm{C}\right)$ and nitrogen $\left({ }^{15} \mathrm{~N} /{ }^{14} \mathrm{~N}\right)$ isotopes. Bone collagen is a protein that can provide an indication of the diet from the last few years of life, depending on the skeletal element (Fahy et al. 2017). In contrast, dentine collagen reflects the diet during tooth formation (Beaumont et al. 2015).

$\mathrm{C}_{3}$ and $\mathrm{C}_{4}$ plants present different enrichment of ${ }^{13} \mathrm{C}$ in their tissues, according to the photosynthetic pathways that they follow. $\mathrm{C}_{3}$ plants are found in temperate climates and include most of the domesticated plants common in Iberian cuisine, including wheat, barley, rice, legumes, tubers, and nuts, and have a lower carbon stable isotope ratio ( -33 to $22 \%$ o), while $\mathrm{C}_{4}$ plants, such as maize, millet, sugarcane, and sorghum, are mostly found in tropical climates and have higher $\delta^{13} \mathrm{C}(-16$ to $-9 \%$ ) (Van der Merwe 1982; DeNiro 


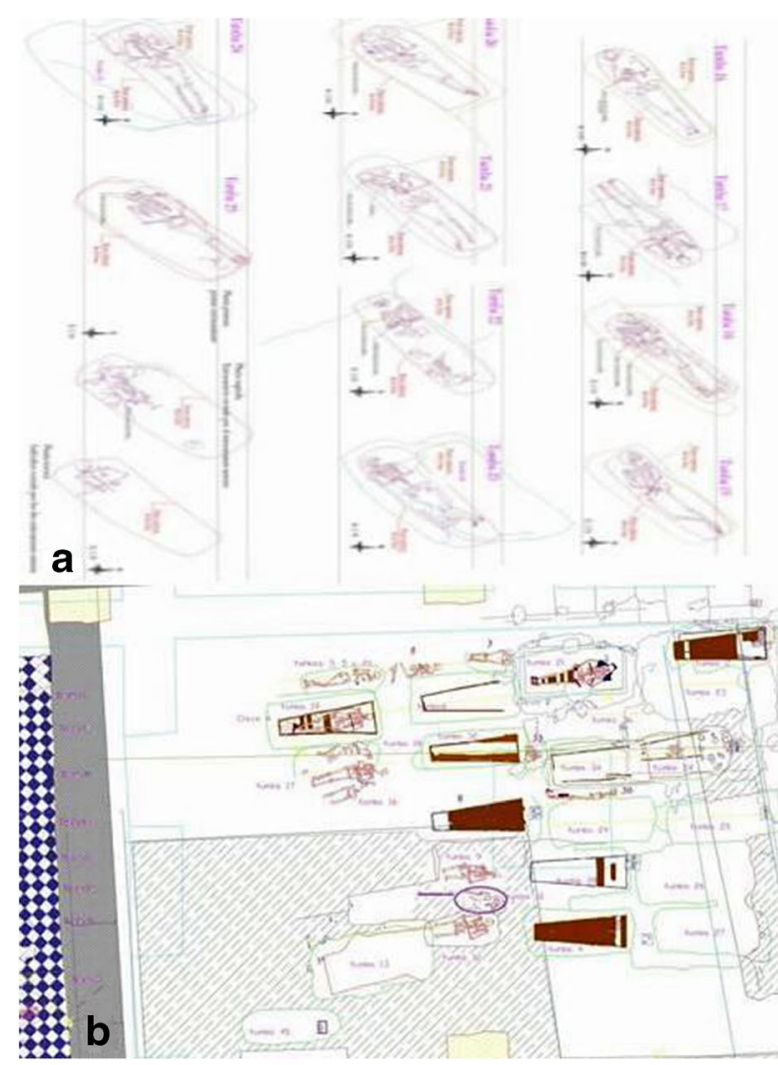

Fig. 1 Monastery in Belmonte. a Distribution and position of individuals from POB MON 1 found in the cloister area. $\mathbf{b}$ Distribution and position of individuals from POB MON 2 found in the choir. $\mathbf{c}$ The map of Spain.

1987). Their differing levels of discrimination against the ${ }^{13} \mathrm{C}$ can be utilised used as a "marker" to trace the presence and relative quantities of these plants in the human diet. Carbon isotope relative abundances also differ in terrestrial and marine environments, as the main source of carbon in the terrestrial environments is atmospheric $\mathrm{CO}_{2}$ and in the marine environment it tends to be dissolved carbonates, with very distinct isotopic signatures (Schoeninger and DeNiro 1984). Marine environment values are normally close to the $\mathrm{C}_{4}$ plants' ratios, with the consequent limitation being to distinguish between both as a source of ${ }^{13} \mathrm{C}$ enrichment on collagen.

Stable isotope values in nitrogen are related to the trophic level in the food chain. Every increment in the position in the food web is followed by a stepwise increase in $\delta^{15} \mathrm{~N}$ fluctuating between +3 and $+5 \%$ (DeNiro and Epstein 1981; Hedges and Reynard 2007; Ambrose 1990; Bocherens and Drucker 2003; Schoeninger and DeNiro 1984), or even $+6 \%$ o (O'Connell et al. 2012). The ${ }^{15} \mathrm{~N}$ enrichment is linked to isotope fractionation during non-essential amino acids' synthesis and the breaking down of any excess protein not being used for tissue building (Reitsema 2013). The $\delta^{15} \mathrm{~N}$ also elevated if large marine organisms are consumed (e.g. large fish, cephalopods), since trophic webs in the aquatic ecosystem are more complex and include more steps than terrestrial ones (Larsen 2002; Chisholm et al. 2006).

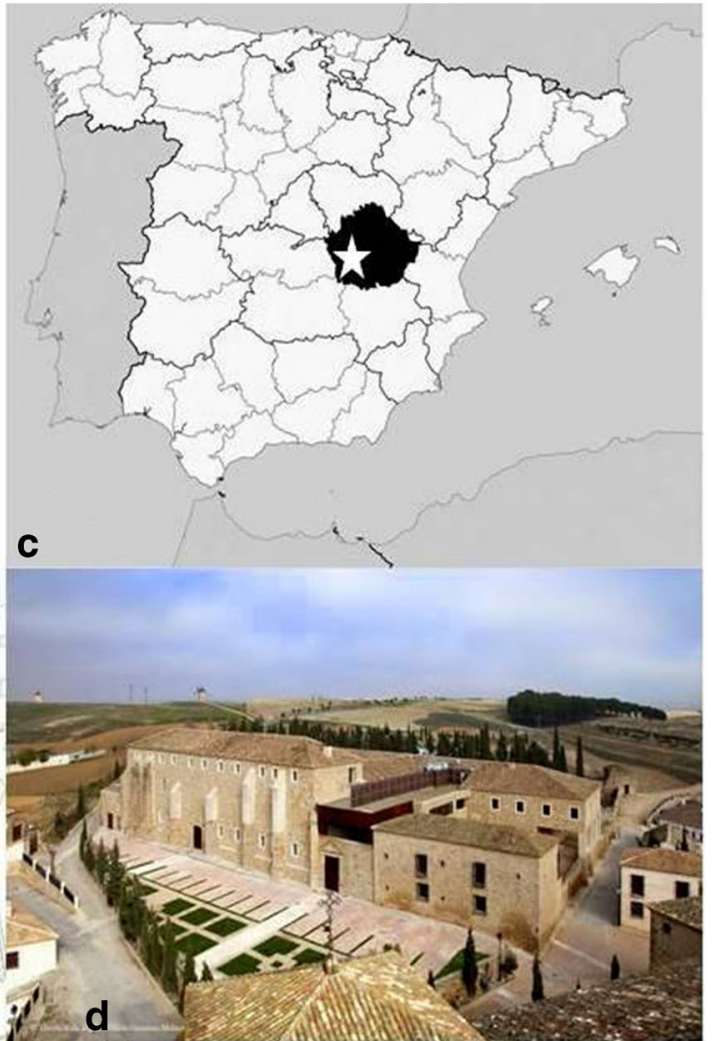

The black region represents the province Cuenca and the white star the town Belmonte. d Ancient fortress Infante Don Juan Manuel

The stable isotopes of $\mathrm{C}$ and $\mathrm{N}$ in bone collagen and bone or dental apatite have become practically indispensable in palaeodiet studies (Lee-Thorp 2008; Schwarcz and Schoeninger 2012). However, the baseline values for a given region and period are not always known. Environmental conditions, such as temperature and humidity, cause variations in the activity of nitrifying the bacteria prevalent in soils or in how plants take up their $\mathrm{CO}_{2}$. Therefore, there are variations in the isotopic baseline depending on altitude, latitude, climate, etc. (Goude and Fontugne 2016). A comparison between absolute isotopic values of one population and another is not always possible, and it is desirable to have a base value obtained from contemporary animals; for example, domestic livestock or species presumably for human consumption (Casey and Post 2011).

\section{Monastic diet}

There are four chief sources that can be used in order to obtain information about the diet of nuns: historical sources (such as expenses books, recipes, and book of monastery rules), zooarchaeological sources (animal bones found during excavations), analyses of skeletal remains, and isotopic analysis. The problem with the written sources is that the information contained in expenses books regarding food is most of the 
time connected to extra food ordered for celebrations, or for when important figures were visiting (Sarkic 2017). Those lists certainly do not represent the everyday life and diet of nuns; because they had very established habits in every aspect of their life, it seems that there was no need to make a list of common supplies. This kind of information can therefore be considered supplementary data, but is not necessarily a reliable guide. In addition, one cannot necessarily use monastic rules to reconstruct monastic diets; just because certain rules existed does not necessarily mean that everyone followed them.

An analysis of zooarchaeological data can help to detect the kinds of animals used in a monastery for primary (meat) and secondary use (such as eggs, wool, and milk), but because excavations of animal remains, and especially those from waste pits, are usually not performed meticulously and based on the rules of stratigraphy, it is hard to conclude whether these animals were killed for a special occasion, or if they were regularly used for food. Another problem with coming to conclusions about diet based on animal bones is that not all the food made in a convent was for nuns; monastery books and other sources of historical data mention lay sisters, novices, labourers (whenever there was a need to fix old or build new parts of a convent), and even servants in richer monasteries (Rey Castelao 2009).

A paleopathological study of human remains can shed light on everyday food consumption. However, some pathological features and diseases that are consider to be an important indicators of episodes of starvation or (such as enamel hypoplasia, rickets, cribra orbitalia, femoral and humeral cribra, and Harris lines) are associated with early childhood or growth. This is a problem when studying nuns; it is known from historical sources that novices usually entered a convent between the ages of 12 and 16 (Bamji 2016; De Maeyer et al. 2004), so by analysing such markers, it is possible to detect malnutrition episodes that occurred before the subjects entered a monastery, but not those that happened after they had taken their vows. Other pathological disorders that can be detected on adult bones such as scurvy (Ortner 2003) and porotic hyperostosis (Walker et al. 2009) among others can be the result of malnutrition, while DISH has been connected to nutritional disorders such as obesity, diabetes, and vitamin deficiencies (Rogers and Waldron 2001; Roberts and Manchester 2005; Mays 2006). However, those changes on the skeletal material reveal an extreme lack or overconsumption of a specific nutrient, and although they are also relevant to this type of analysis, the stable isotope method is considered the most complete, when studying a population's diet.

\section{The aim of the study}

Despite the relative availability of works dealing with religious communities' food and everyday life (Müldner and Richards 2005, 2007; Polet and Katzenberg 2003; Müldner et al. 2009; Yoder 2012; Bownes et al. 2018; Gregoricka and Guise Sheridan 2013; Quintelier et al. 2014), they are almost exclusively focused on males - i.e. monks - and none was centred on monastic populations in Spain, meaning that the habits of cloistered nuns in Spain have so far been ignored in bioarchaeological research. This being so, the aim of this study is to isotopically characterise the individuals of a female religious community with a particular and, presumably, uniform diet in relation to their state of health in order to test:

- Any agreement between the diet type suggested by the isotope signatures and historical records

- The possibility of a connection between chronic diseases and isotopic signatures

- The existence of differences in lifestyle between the two periods represented by POB MON 1 and POB MON 2.

\section{Materials and methods}

\section{Faunal remains}

The samples studied come from a non-systematic collection of bone remains from what were probably kitchen waste pits. Because the sample is biased, given that not all bone remains were collected, their quantitative study cannot provide data on community food preferences, and it is also not possible to calculate its chronology. However, species identification and isotopic studies provide an important baseline on which to interpret human isotopic signals. The most abundant remains are from sheep, whose long bones indicate that adult animals aged between 18 and 24 months at the time of death, as calculated from the degree of epiphyseal fusion (Zeder 2006; Zeder and Lapham 2010). All the samples of chickens show them to have been adults with a total fusion of epiphysis, with a size that is smaller than contemporary hens. Among the total set of skeletal remains of this species analysed during the procedure, there was one tarsal-metatarsal with no spur (probably female, because it is too small to be a castrated male). In two of the long bones (a femur and, less markedly, in a tibiotarsus), the medullar cavity, usually hollow, was occupied with the medullary bone, which is characteristic of nesting females (Driver 1982). All this information seems to indicate that they were laying hens. During excavation, plenty of eggshells were observed which, unfortunately, were not available for our study (Caballero and Sánchez 2013). It is noteworthy that eggs have been documented in monastic recipes, being frequently used for sweets and soups, as well as fried (Alperi and Fernandez 2012). Other faunal remains are less represented in the sample: there were some of pigs (at least one domestic individual and a wild boar), one duck premaxilla, several fish remains, at least one catshark (Scyliorhinidae), and some bony fish identified as hake (Merluccius sp.) and salmon (Salmo sp.). 


\section{Human remains}

As mentioned before, an ancient fortress was converted in the Dominican convent of Santa Catalina de Siena in the sixteenth century and lasted until 1960. Therefore, it was expected that most nuns were buried there. The study of skeletal remains and more specifically the sex estimation supports this assumption: 76 females, 1 probable male, 8 indeterminate adults, and 1 subadult in POB MON 1; 26 females and 5 indeterminate adults in POB MON 2 (Sarkic 2017). In addition, POB MON 1 is divided into two periods of use, according to its stratigraphy: the late sixteenth century-"below", and the seventeenth century-"above" (Caballero and Sánchez 2013).

For the sex estimation, the usual anthropologic methods were used based on morphological characteristics of the coxal (Phenice 1969; Buikstra and Meilke 1985; Milner 1992; Bruzek 2002; Walker 2005), the skull (Acsádi and Nemeskeri 1970; Buikstra and Ubelaker 1994), and mandibular ramus (Loth and Henneberg 1998) (Table 1). The combination of coxal and skull sex estimation was used whenever the preservation allowed so as to obtain the highest possible accuracy (97\%, according to Meindl et al. 1985).

The statistical comparison between the two monastic populations did not show any significant differences in life expectancy, stature, entheseal changes, frequency and degree of OA, nor frequency of dental diseases, except for caries (Chi-square test $p=0.003$ ), the occurrence of which increased with time (Sarkic 2017). In POB MON 1, caries was observed in $18.92 \%$ of individuals with preserved teeth, while in POB MON 2, 25.92\% of individuals had this pathology. This could suggest that the lifestyle of the nuns did not experience any significant changes over the past century, except that dental hygiene became worse and/ or they began using new foodstuffs that were more likely to cause caries. Most individuals from POB MON 1 (59.4\%) have been classified as mature adults aged over 40 . Despite the advanced average age (for the epoch), pathological signs were not common. In POB MON 2, 87.5\% individuals were over 40 . In this population, the number of pathologies was higher (in proportion with the number of individuals), including osteomalacia, brucellosis, tuberculosis, and breast cancer.

\section{Samples}

For the isotopic analysis, 88 samples were selected (Table 2). In total, 65 humans from POB MON 1 and 9 from POB MON 2 were analysed. None of the samples were taken from areas with visible bone pathology, which could alter the isotopic signals (Katzenberg and Lovell 1999; Olsen et al. 2014). The fauna were composed of sheep (seven), hens (three), pigs (two), and fish (two), all taken from different individuals (Table 2).

The best-preserved human skeletal remains were sampled, covering groups that ranged in age from sub-adults (1418 years) to older adults ( +60 years), sex (one of the individuals was possibly male, while the others were females), and health conditions (some of the individuals showed signs of chronic diseases such as brucellosis, leprosy, cancer, tuberculosis, and osteoporosis). Although the main focus of this article is on adult females from the monastic population, the analysis of the diet of sub-adults and a possibly male individual will yield important information about life in convents and respect of the general monastic rules. Because the rules of the Dominican Order emphasise that the sick and children under 14 can be excluded from fasting, it was expected for that their isotopic signal would be different. In the case of the possibly male individual, if the isotopic signal was similar to that other the nuns that could mean that he (?) lived with them in the same convent, while any differences could indicate that he (?) was only buried there, or received some kind of special treatment. The sampled bones in POB MON 1 were mainly skull fragments $(n=32)$ and ribs $(n=21)$. There were also eight long bone diaphysis, three vertebrae, and one jaw fragment (see Table 2). For POB MON 2, all the samples were ribs, except for one metacarpal.
Table 1 Methods used for the sex estimation based on morphological characteristics of the coxal and skull

\begin{tabular}{lll}
\hline Sex estimation methods & & \\
\hline Method & Author(s) & Reliability \\
\hline $\begin{array}{l}\text { Subpubic region — the ventral arc, the subpubic } \\
\text { concavity and the ischiopubic ramus ridge }\end{array}$ & Phenice (1969); Buikstra and Meilke (1985) & $96 \%$ \\
$\begin{array}{l}\text { Great sciatic notch } \\
\begin{array}{l}\text { Skull—nuchal crest, the mastoid process, the } \\
\text { supraorbital ridges, the glabellar region and } \\
\text { the mental eminence in the mandible }\end{array}\end{array}$ & $\begin{array}{l}\text { Milner (1992); Bruzek (2002); Walker (2005) } \\
\text { Mandibular ramus }\end{array}$ & $95-96 \%$ \\
& Lothelaker (1994) & $92 \%$ \\
\hline
\end{tabular}


Table 2 Data from faunal remains in the convent of Santa Catalina de Siena (Belmonte, Spain). Species, bone analysed, quality indicators of bone collagen, and isotopic values obtained

\begin{tabular}{llllllllll}
\hline Fauna & Bone & Observations & $\% \mathrm{~N}$ os & Collagen yield $\%$ & $\%$ Ccol & $\%$ Ncol & C/N at & $\delta^{13} \mathrm{C}_{\mathrm{VPDV}}(\%)$ & $\delta^{15} \mathrm{~N}_{\mathrm{AIR}}(\%)$ \\
\hline Catshark & Vertebra & & n.d. & 11.5 & 39.70 & 14.60 & 3.2 & -11.3 & 11.2 \\
Gallus 1 & Tibiotarsus & & 1.14 & 8.5 & 38.60 & 14.00 & 3.2 & -19.9 & 7.8 \\
Gallus 2 & Tibiotarsus & & 0.68 & 7.8 & 40.10 & 14.60 & 3.2 & -19.3 & 8.6 \\
Gallus 3 & Tibiotarsus & & 1.04 & 11.6 & 39.40 & 14.40 & 3.2 & -19.6 & 9.4 \\
Ovis 1 & Tibia & Left & 1.07 & 9.7 & 39.60 & 14.80 & 3.1 & -19.4 & 7.3 \\
Ovis 2 & Tibia & Left & 0.86 & 8.5 & 39.70 & 14.70 & 3.2 & -20.7 & 7.4 \\
Ovis 3 & Tibia & Left & 0.82 & 8.4 & 39.50 & 14.70 & 3.1 & -19.7 & 9.6 \\
Ovis 4 & Tibia & Left & 0.97 & 17.6 & 39.80 & 14.90 & 3.1 & -20.1 & 9.1 \\
Ovis 5 & Tibia & Left & 1.23 & 20.4 & 39.80 & 14.80 & 3.1 & -21.0 & 6.6 \\
Ovis 6 & Tibia & Left & 1.01 & 19.9 & 39.80 & 14.80 & 3.1 & -19.9 & 8.9 \\
Ovis 7 & Tibia & Left & 1.09 & 10.0 & 38.30 & 14.30 & 3.1 & -20.1 & 8.3 \\
Sus domesticus & Metapodium & & 1.92 & 20.8 & 39.80 & 14.90 & 3.1 & -19.3 & 9.9 \\
Sus scrofa & Maxila & & 1.11 & 10.6 & 40.45 & 14.90 & 3.2 & -18.7 \\
\hline
\end{tabular}

\section{Treatment of the samples}

The surface of each bone and all traces of cancellous bone in the ribs or long bone fragments were removed, using a dental drill equipped with an abrasive disc. The cranial fragments were treated as a whole, with the bone chunks sonicated in at least five different baths. The cleaned samples were dried at room temperature for $48 \mathrm{~h}$ and then ground into powder $(0.5 \mathrm{~mm}$ sieve) with an agate mortar and pestle. As an initial approximation of collagen preservation (Bocherens et al. 2005), we conducted an elemental analysis of $\mathrm{C}$ and $\mathrm{N}$ proportions in bulk bone powder, except in some cases in which the obtained bone powder was too limited, and the entire sample was reserved for isotopic analysis. Although most of the skull fragments yielded a low content of $\mathrm{N}$ (under 0.3\%), all were included in the analysis.

The collagen extraction was carried out according to the procedure described by Longin (1971) and Bocherens et al. (1997). Three hundred milligrams of bone powder was first demineralised in $\mathrm{HCl}$ solution (1 M, $20 \mathrm{~min}$, room temperature) and filtered $(5 \mu \mathrm{m})$. The residue was soaked in $\mathrm{NaOH}$ solution $(0.125 \mathrm{M}, 20 \mathrm{~h}$, room temperature), filtered $(5 \mu \mathrm{m})$, and solubilised in a weak acid solution $(\mathrm{HCl}, 0.01 \mathrm{M}, 17 \mathrm{~h}$, $\left.100{ }^{\circ} \mathrm{C}\right)$. The dissolved collagen solution was filtered $(5 \mu \mathrm{m})$ and freeze-dried for $48 \mathrm{~h}$.

Stable isotope ratios $\left({ }^{13} \mathrm{C} /{ }^{12} \mathrm{C}\right.$ and $\left.{ }^{15} \mathrm{~N} /{ }^{14} \mathrm{~N}\right)$ of the extracted collagen were performed using an Elemental Analyser FlashEA 1112 (ThermoFinnigan) connected through a Conflo II (ThermoFinnigan) interface to a Delta plus (ThermoFinnigan) isotopic relationship Mass Spectrometer, in the Instrumental Analysis Techniques Unit (UTIA) of the Research Support Services of University of A Coruña. Analytical reproducibility is better than $0.2 \%$ of both $\delta^{13} \mathrm{C}$ and $\delta^{15} \mathrm{~N}$. The internal standard was acetanilide, and all data were averaged from the two replicates.
Stable isotope ratios are expressed with delta notation $\left(\delta^{13} \mathrm{C}, \delta^{15} \mathrm{~N}\right)$ in parts per thousand $(\% \circ)$ relative to international standards, VPDB for C and AIR for N, respectively. Collagen preservation was tested based on quality and quantity factors, which can be summarised as follows: Yield $\geq 1.5 \%$ (Ambrose 1990); \%C $\geq 13 \%$ and $\% N \geq 5 \%$ (Ambrose 1990), C/N ratio within the range of 2.9 to 3.6 (DeNiro 1985).

The statistical analysis was performed using the PAST package (Hammer et al. 2001).

\section{Results}

\section{Collagen quality}

Collagen quality indicators are presented in detail in Table 2 (faunal remains), Table 3 (POB MON 1, sixteenth to seventeenth century), and Table 4 (POB MON 2, nineteenth to twentieth century). All the animal samples, except one (a fish vertebra with atomic $\mathrm{C} / N=3.8$ ), yielded good-quality collagen. In POB MON 1, 16 of 65 samples had poorly preserved collagen, recognisable by yields below the acceptable threshold and/or a $\mathrm{C} / \mathrm{N}$ ratio outside the recommended range. The remaining 49 bone samples showed a $\mathrm{C} / \mathrm{N}$ ratio in the acceptable range and $\mathrm{C}$ and $\mathrm{N}$ content over the threshold (Ambrose 1990). A total of 43 (81.2\% of the accepted samples) met a more restrictive requirement, with $\mathrm{C}>30 \%$ and $N>11 \%$ (Van Klinken 1999). In POB MON 2, all nine bone samples analysed yielded good-quality collagen. In total, we gained wellpreserved collagen and isotopic data from 58 humans and 13 faunal remains. 
Table 3 Data of the individuals from POB MON 1 (sixteenth to seventeenth century) found in the convent of Santa Catalina de Siena (Belmonte, Spain). Tomb number and individual, type of bone analysed, age and sex of the individual ( $\mathrm{F}$ - female, $\mathrm{M}-$ male, and $\mathrm{I}-$ indeterminate), position, pathologies and/or other observations, quality indicators of bone collagen, and isotopic values obtained

\begin{tabular}{|c|c|c|c|c|c|c|c|c|c|c|c|c|}
\hline $\begin{array}{l}\text { Tomb- } \\
\text { individual }\end{array}$ & Bone & Sex & Age & Stratigraphy & Observations & $\begin{array}{l}\% \\
\text { Nos }\end{array}$ & $\begin{array}{l}\text { Collagen } \\
\text { yield } \%\end{array}$ & $\begin{array}{l}\% \\
\text { Ccol }\end{array}$ & $\begin{array}{l}\% \\
\text { Ncol }\end{array}$ & $\begin{array}{l}\mathrm{C} / \mathrm{N} \\
\text { at }\end{array}$ & $\begin{array}{l}\delta^{13} \mathrm{C}_{\mathrm{VPDV}} \\
(\% o)\end{array}$ & $\begin{array}{l}\delta^{15} \mathrm{~N}_{\mathrm{AIR}} \\
(\% \mathrm{)})\end{array}$ \\
\hline $2-11$ & Rib & F & $19-25$ & Below & & 3.0 & 20.3 & 41.4 & 15.2 & 3.2 & -18.4 & 11.0 \\
\hline $2-12$ & Femur & $\mathrm{F}$ & $40-59$ & Below & & 0.4 & 2.1 & 27.5 & 9.1 & 3.5 & -18.3 & 11.4 \\
\hline $3-11$ & $\mathrm{Rib}$ & $\mathrm{F}$ & $40-59$ & Below & & 3.9 & 18.9 & 41.8 & 15.4 & 3.2 & -17.9 & 11.5 \\
\hline $3-12$ & Rib & I & $40-59$ & Below & Brucellosis & 2.5 & 13.2 & 40.1 & 14.7 & 3.2 & -18.0 & 11.5 \\
\hline $4-11$ & Skull & M & $40-59$ & Below & & 0.8 & 5.2 & 37.2 & 13.4 & 3.2 & -18.1 & 11.4 \\
\hline $6-11$ & Femur & $\mathrm{F}$ & $>60$ & Below & & 0.4 & 2.2 & 34.0 & 11.1 & 3.6 & -18.2 & 11.9 \\
\hline $6-12$ & $\mathrm{Rib}$ & $\mathrm{F}$ & $25-39$ & Below & Osteoporosis & 1.6 & 10.7 & 41.2 & 15.1 & 3.2 & -17.9 & 11.0 \\
\hline $6-13$ & Skull & $\mathrm{F}$ & $>60$ & Below & & 1.0 & 5.9 & 39.0 & 14.6 & 3.1 & -18.4 & 11.4 \\
\hline $8-11$ & Rib & I & $25-39$ & Below & & 1.0 & 7.1 & 32.5 & 11.9 & 3.2 & -18.4 & 9.9 \\
\hline $8-14$ & Rib & I & $25-39$ & Below & & 1.7 & 9.9 & 39.5 & 14.6 & 3.2 & -18.1 & 10.3 \\
\hline $9-21$ & Peroné & $\mathrm{F}$ & $>60$ & Above & & 1.9 & 17.6 & 36.5 & 13.4 & 3.2 & -18.0 & 10.7 \\
\hline $9-22$ & Skull & $\mathrm{F}$ & $14-18$ & Below & Youngest & 0.3 & 1.9 & 24.7 & 8.0 & 3.6 & -18.2 & 12.7 \\
\hline $9-25$ & Skull & $\mathrm{F}$ & Indeterminate & Below & & 0.5 & 3.6 & 29.2 & 10.0 & 3.4 & -17.7 & 12.6 \\
\hline $10-22$ & Rib & $\mathrm{F}$ & $25-39$ & Below & & 2.0 & 16.0 & 35.0 & 13.0 & 3.1 & -18.0 & 10.3 \\
\hline $10-26$ & Skull & $\mathrm{F}$ & $>60$ & Below & & 1.3 & 12.1 & 39.2 & 14.6 & 3.1 & -18.4 & 10.6 \\
\hline $10-27$ & Skull & $\mathrm{F}$ & $40-59$ & Below & & 1.0 & 6.9 & 37.4 & 13.9 & 3.1 & -18.3 & 11.6 \\
\hline $11-12$ & Skull & $\mathrm{F}$ & $40-59$ & Below & & 3.1 & 18.9 & 40.1 & 14.5 & 3.3 & -17.7 & 11.7 \\
\hline $11-13$ & Femur & $\mathrm{F}$ & $40-59$ & Below & & 3.6 & 27.1 & 39.2 & 14.6 & 3.1 & -18.5 & 10.2 \\
\hline $12-0$ & Vertebra & $\mathrm{F}$ & Indeterminate & Below & & 3.2 & 22.4 & 39.5 & 14.8 & 3.1 & -18.2 & 11.6 \\
\hline $12-22$ & Jaw & $\mathrm{F}$ & $40-59$ & Below & & 1.0 & 7.1 & 36.9 & 13.6 & 3.2 & -18.0 & 10.7 \\
\hline $12-23$ & Skull & $\mathrm{F}$ & $40-59$ & Below & & 2.6 & 22.2 & 40.5 & 14.6 & 3.2 & -17.5 & 10.7 \\
\hline $12-24$ & Skull & $\mathrm{F}$ & $25-39$ & Above & & 1.3 & 18.5 & 39.4 & 13.9 & 3.3 & -16.2 & 13.9 \\
\hline $13-3$ & Skull & $\mathrm{F}$ & $40-59$ & Below & & 0.4 & 2.4 & 34.3 & 11.8 & 3.4 & -18.0 & 11.8 \\
\hline $13-4$ & Skull & $\mathrm{F}$ & $40-59$ & Below & & 0.4 & 1.8 & 31.5 & 10.7 & 3.4 & -18.4 & 12.0 \\
\hline $13-6$ & Skull & $\mathrm{F}$ & $40-59$ & Below & & 0.5 & 2.9 & 36.3 & 12.8 & 3.3 & -18.4 & 11.7 \\
\hline $13-7$ & Rib & $\mathrm{F}$ & $40-59$ & Below & TBC? & 3.3 & 22.2 & 39.3 & 14.5 & 3.2 & -17.7 & 11.5 \\
\hline $13-7$ & Skull & $\mathrm{F}$ & $40-59$ & Below & TBC? & 1.8 & 13.9 & 39.7 & 14.9 & 3.1 & -18.2 & 10.6 \\
\hline $14-11$ & Rib & $\mathrm{F}$ & $40-59$ & Above & & 3.7 & 25.4 & 39.4 & 14.6 & 3.2 & -18.3 & 10.5 \\
\hline $14-14$ & Skull & $\mathrm{F}$ & $19-25$ & Below & & 0.3 & 3.5 & 35.3 & 11.5 & 3.1 & -18.0 & 11.5 \\
\hline $14-16$ & Rib & $\mathrm{F}$ & $>60$ & Below & & 4.2 & 32.6 & 38.4 & 14.3 & 3.1 & -18.1 & 12.5 \\
\hline $15-13$ & Rib & $\mathrm{F}$ & $40-59$ & Above & & 3.8 & 25.8 & 41.2 & 15.0 & 3.2 & -18.1 & 11.7 \\
\hline $15-14$ & Vertebra & $\mathrm{F}$ & $40-59$ & Below & & 3.2 & 21.7 & 40.7 & 14.7 & 3.2 & -18.0 & 12.0 \\
\hline $16-11$ & Rib & $\mathrm{F}$ & $25-39$ & Above & & 2.7 & 26.9 & 16.5 & 5.3 & 3.6 & -18.2 & 11.5 \\
\hline $17-11$ & Rib & $\mathrm{F}$ & $25-39$ & Above & & 2.1 & 30.8 & 16.5 & 5.4 & 3.6 & -18.1 & 11.3 \\
\hline $18-12$ & Rib & $\mathrm{F}$ & $19-25$ & Above & $\begin{array}{l}\text { Cribra } \\
\text { femoralis }\end{array}$ & 3.9 & 6.10 & 25.4 & 8.7 & 3.4 & -17.9 & 12.6 \\
\hline $18-13$ & Femur & $\mathrm{F}$ & $40-59$ & Below & & 3.3 & 5.8 & 19.7 & 6.7 & 3.5 & -18.0 & 12.0 \\
\hline $18-14$ & Humerus & $\mathrm{F}$ & $>60$ & Below & Osteoporosis & 3.4 & 7.1 & 24.2 & 8.2 & 3.4 & -18.1 & 11.6 \\
\hline $19-12$ & Rib & $\mathrm{F}$ & $19-25$ & Above & & 2.1 & 25.4 & 14.7 & 5.0 & 3.5 & -18.0 & 12.1 \\
\hline $20-31$ & Rib & $\mathrm{F}$ & $40-59$ & Above & & 3.8 & 23.2 & 40.0 & 15.0 & 3.1 & -18.1 & 11.6 \\
\hline $20-32$ & Rib & $\mathrm{F}$ & $>60$ & Below & & 3.8 & 27.1 & 39.3 & 14.6 & 3.1 & -17.7 & 11.6 \\
\hline $21-13$ & Skull & $\mathrm{F}$ & $25-39$ & Below & & 1.8 & 22.9 & 39.6 & 14.5 & 3.2 & -18.6 & 9.7 \\
\hline $22-12$ & Rib & $\mathrm{F}$ & $25-39$ & Above & Periostitis & 1.9 & 12.4 & 38.7 & 14.5 & 3.1 & -18.0 & 11.6 \\
\hline $23-12$ & Skull & $\mathrm{F}$ & $>60$ & Below & & 1.7 & 15.5 & 38.3 & 14.0 & 3.2 & -18.1 & 11.5 \\
\hline $23-13$ & Vertebra & $\mathrm{F}$ & $25-39$ & Below & & 1.6 & 13.6 & 39.5 & 14.3 & 3.2 & -17.5 & 10.9 \\
\hline $24-16$ & Rib & $\mathrm{F}$ & $40-59$ & Above & & 2.9 & 19.9 & 38.2 & 14.4 & 3.1 & -17.8 & 12.4 \\
\hline $25-1$ & Rib & $\mathrm{F}$ & $>60$ & Below & Osteoporosis & 4.2 & 25.8 & 39.7 & 14.8 & 3.1 & -17.7 & 12.3 \\
\hline $25-2$ & Rib & $\mathrm{F}$ & $40-59$ & Below & & 2.1 & 18.0 & 39.1 & 14.7 & 3.1 & -18.5 & 10.9 \\
\hline $25-3$ & Fibula & $\mathrm{F}$ & $25-39$ & Above & & 2.7 & 21.0 & 35.7 & 13.4 & 3.1 & -17.8 & 11.7 \\
\hline $25-4$ & Skull & $\mathrm{F}$ & $>60$ & Below & & 2.6 & 19.1 & 40.3 & 14.5 & 3.2 & -18.0 & 11.7 \\
\hline
\end{tabular}

In the human remains, most of the refused samples (15 of 16) were skull fragments, and one was a fragment of the femur. After the samples that did not reach the quality indicators were discarded, both the collagen yield and collagen $\mathrm{N}$ percentage showed statistically significant median differences between ribs and skull fragments (Mann-Whitney $U$ with
Monte Carlo permutation, $P=0.0001)$. The collagen $\mathrm{C}$ percentage showed no significant difference, and the ribs and long bones showed no significant differences in any parameters. This demonstrates that for the Belmonte collection, ribs and long bones seem to contain better-preserved collagen than skull fragments. 
Table 4 Data of the individuals from the nineteenth to twentieth century (POB MON 2) found in the convent of Santa Catalina de Siena (Belmonte, Spain). Tomb number and individual, type of bone analysed, age and sex of the individual ( $\mathrm{F}$ - female), pathologies and/or other observations, quality indicators of bone collagen, and isotopic values obtained

\begin{tabular}{llllllllllll}
\hline Group & $\begin{array}{l}\text { Tomb/ } \\
\text { individual }\end{array}$ & Bone & Sex & Age & Observations & $\begin{array}{l}\text { Collagen } \\
\text { yield } \%\end{array}$ & \% Ccol & $\%$ Ncol & C/N at & $\delta^{13} \mathrm{C}_{\text {VPDV }}(\%$ o $)$ & $\delta^{15} \mathrm{~N}_{\text {AIR }}(\%$ o $)$ \\
\hline POB MON 2 & T-4 & Rib & F & $40-59$ & Leprosy & 19.5 & 34.1 & 12.4 & 3.2 & -18.7 & 12.4 \\
POB MON 2 & T-21 & Rib & F & $25-39$ & & 20.0 & 40.7 & 14.7 & 3.2 & -15.7 & 11.1 \\
POB MON 2 & T-23 & Rib & F & $40-59$ & & 26.5 & 41.8 & 15.0 & 3.2 & -18.6 & 12.3 \\
POB MON 2 & T-24 & Metacarpal & F & $40-59$ & Cancer & 24.7 & 37.7 & 13.7 & 3.2 & -15.7 & 11.4 \\
POB MON 2 & T-28A & Rib & F & $40-59$ & Brucellosis & 27.2 & 40.8 & 14.7 & 3.2 & -15.8 & 11.7 \\
POB MON 2 & T-28B & Rib & F & $40-59$ & & 24.2 & 40.8 & 14.8 & 3.2 & -18.3 & 10.4 \\
POB MON 2 & T-30 & Rib & F & +60 & & 23.1 & 36.4 & 13.2 & 3.2 & -17.9 & 12.6 \\
POB MON 2 & T-36 & Rib & F & $40-59$ & & 19.0 & 41.2 & 14.7 & 3.3 & -17.8 & 13.0 \\
POB MON 2 & T-44 & Rib & F & $40-59$ & & 23.9 & 37.6 & 13.6 & 3.2 & -18.6 & 12.0 \\
\hline
\end{tabular}

\section{Faunal remains}

Figure 2 shows the isotope data of bone collagen that are listed in Tables 2, 3, and 4 and summarised in Table 5. The terrestrial fauna (Table 2) presented a moderate isotopic variability in $\delta^{15} \mathrm{~N}$, with the sheep showing the lowest mean values $\left(\delta^{15} \mathrm{~N}=8.2 \pm 1.1 \%\right.$ o). In Gallus, the mean value was slightly higher $\left(\delta^{15} \mathrm{~N}=8.6 \pm 0.8 \%\right.$ ). The pigs, both domestic and wild, showed higher nitrogen signatures than all other terrestrial animals $\left(\delta^{15} \mathrm{~N}=9.0\right.$ and $9.9 \%$, respectively). Terrestrial animals' $\delta^{15} \mathrm{~N}$ ranges from 6.6 to $9.9 \%$, while $\delta^{13} \mathrm{C}$ ranged from -21.0 to $-18.7 \%$, suggesting that $\mathrm{C}_{4}$ plants were not the dietary staple. The analysed fish (a catshark vertebra) showed a clear marine signature, $\delta^{13} \mathrm{C}=-11.3 \%$.

\section{Isotope signatures in POB MON 1}

Although the bone collagen values from POB MON 1 (Table 3) presented dispersion, only 1 of the 49 individuals had significant different signatures, especially in the $\delta^{13} \mathrm{C}$ values (Grubbs' test $G=, p=0.001$ for $\delta^{13} \mathrm{C}$ and $G=, p=$ 0.055 for $\delta^{15} \mathrm{~N}$; Grubbs 1969) and will be considered separately. Once the outlier had been removed, both isotopes showed distributions that were not significantly different to normal (Shapiro-Wilk $W$ test, $W=, p=0.200$ for $\delta^{13} \mathrm{C}$ and $W=, p=0.127$ for $\left.\delta^{15} \mathrm{~N}\right)$. The average values for the main group were $\delta^{13} \mathrm{C}=-18.1 \pm 0.3$ and $\delta^{15} \mathrm{~N}=11.4 \pm 0.7$. In contrast to the animals, $\delta^{13} \mathrm{C}$ was within a limited range $\left(1.1 \%\right.$ ) , but $\delta^{15} \mathrm{~N}$ showed, as in the sheep, a continuous shift of $3 \%$, between 9.7 and $12.7 \%$. The trophic spacing between the terrestrial animals and the humans for $\delta^{15} \mathrm{~N}$ mean values is barely $3 \%$, not reaching that of one trophic level (O'Connell et al. 2012). For $\delta^{13} \mathrm{C}$, there is an offset of $1.7 \%$, close to the upper limit for a trophic level, according some authors (Bocherens and Drucker 2003; McCutchan et al. 2003).
The outlier individual in POB MON 1 was a young female (aged 25-39) who showed more positive values for both $\delta^{13} \mathrm{C}$ and $\delta{ }^{15} \mathrm{~N}$, in comparison to the rest of the population. No pathological signs on bones, apart from some marginal osteophytes, compatible with an early stage of OA were detected in this individual, and no deviation in funeral practice was observed.

The age of the individuals analysed varies between 14-18 and $>60$, but the isotope values (Fig. 3, Table 6) showed only small statistically significant $(\alpha=0.05)$ differences between any of the established age groups. A Kruskal-Wallis $H$ test with Bonferroni correction yielded no significant differences between the three major age groups in $\mathrm{C}$ and a slight difference in $\mathrm{N}$ isotope values. However, the youngest individual, aged 14-18 years, reached the highest value of $\delta^{15} \mathrm{~N}$, if the "outlier" was not taken into account. A paired comparison (MannWhitney $U$ with Monte Carlo permutation) between age classes yielded slightly significant differences between the medians of the groups from 25 to 39 years old, and all others for $\delta^{15} \mathrm{~N}$. However, these differences could be due to the scarcity of data in some age classes. With regard to sex, a possible male individual (individual 4-11) aged 40-59 showed values that entirely corresponded to the average values of the monastic community. The results also showed that the individuals with detected chronic pathologies (i.e. brucellosis, osteopenia, and periostitis) are within the range of variation of those with no clear pathological features in $\delta^{15} \mathrm{~N}$, but are slightly different $(\alpha=0.10)$ in $\delta^{13} \mathrm{C}$. Finally, there are no significant isotopic differences between individuals deposited below or above in the grave.

\section{Isotope signatures in the nineteenth to twentieth century (POB MON)}

POB MON 2 individuals (Table 4) fall into two separate groups according to their $\delta^{13} \mathrm{C}$. The most numerous one $(n=6)$ showed similar values to the monastic population from 
Fig. 2 Bone collagen isotopic values of POB MON 1 (sixteenth to seventeenth century), $\mathrm{POB}$ MON 2 (nineteenth to twentieth century), POB CIV 2 (nineteenth century), and faunal samples collected in the convent Santa Catalina de Siena in Belmonte (Cuenca, Spain)

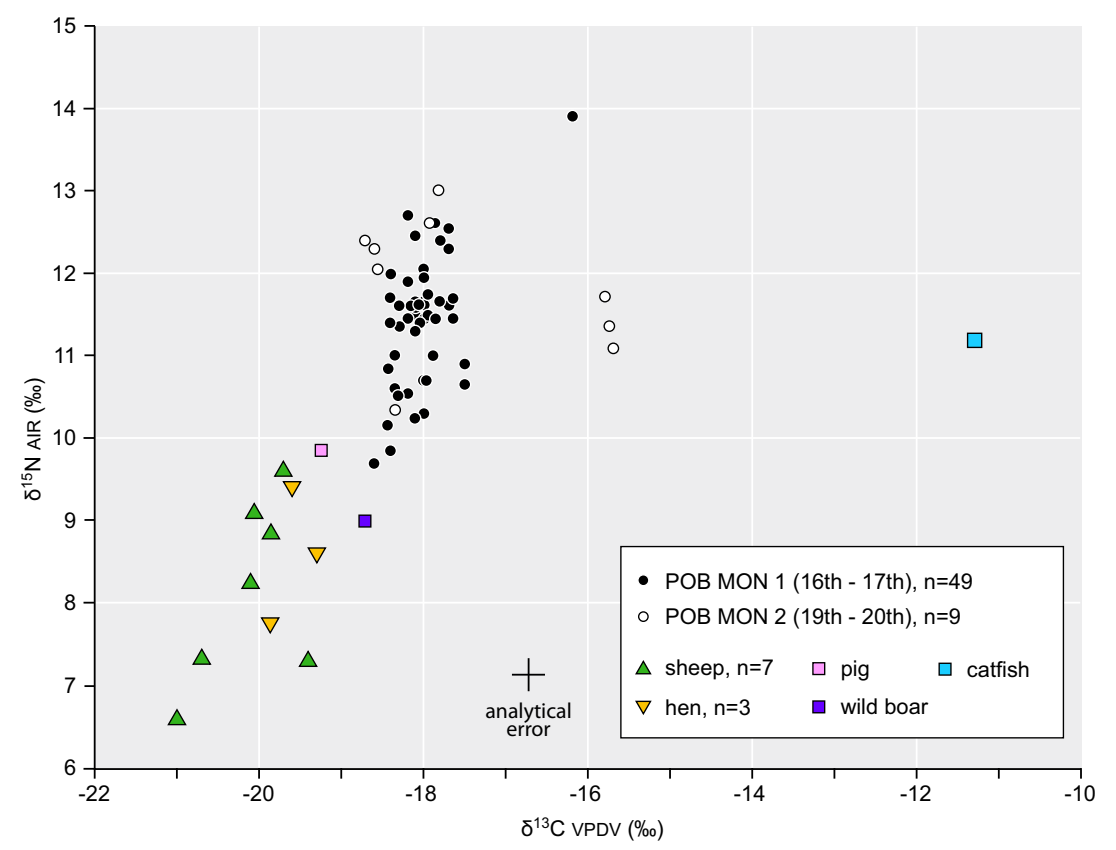

previous centuries (Kruskal-Wallis test with Bonferroni correction, $p=0.1271$ ). The second group, composed of the remaining three individuals, revealed a distinctly enriched $\delta^{13} \mathrm{C}$; two of them had signs of chronicle pathological condition,

Table 5 Summary of isotope values for the three studied human groups and the faunal remains

\begin{tabular}{lll}
\hline & $\delta^{13} \mathrm{C}(\%)$ & $\delta^{15} \mathrm{~N}(\%)$ \\
\hline Human 16th-17th (POB MON 1) & & \\
Average \pm 1 SD & $-18.0 \pm 0.369$ & $11.4 \pm 0.790$ \\
$(n=47)$ (max, min) & $(-18.6$ to -16.2$)$ & $(9.7$ to 13.9$)$ \\
Mean without outlier \pm 1 SD & $-18.1 \pm 0.259$ & $11.4 \pm 0.711$ \\
$(n=46)$ & $(-18.6$ to -17.5$)$ & $(9.7$ to 12.7$)$ \\
Outlier & -16.2 & 13,9 \\
Mean dentine collagen \pm 1 SD & $-18.3 \pm 0.213$ & $9.9 \pm 0.474$ \\
$\quad(n=4)$ & $(-18.4$ to -17.9$)$ & $(9.6$ to 10.6$)$ \\
Human 19th-20th (POB MON 2) & & \\
Mean bone collagen \pm 1SD & $-17.5 \pm 1.328$ & $11.9 \pm 0.814$ \\
$(n=9)$ & $(-18.7$ to -15.7$)$ & $(10.4$ to 13.0$)$ \\
Dentine collagen $n=1$ & -18.6 & 11.3 \\
Human 19th-20th (POB CIV 2) & & \\
Bone collagen $(n=1)$ & -18.1 & 12.3 \\
Fauna & & \\
Sheep mean \pm 1 SD & $-20.1 \pm 0.560$ & $8.2 \pm 1.101$ \\
$(n=7)$ & $(-21.0$ to -19.4$)$ & $(6.6$ to 9.6$)$ \\
Hen mean \pm 1 SD & $-19.6 \pm 0.275$ & $8.6 \pm 0.825$ \\
$(n=3)$ & $(-19.9$ to -19.3$)$ & $(7.8$ to $9.4 \%$ ) \\
Wild pig Sus scrofa & -18.7 & 9.0 \\
Domestic pig Sus domesticus & -19.3 & 9.9 \\
Catshark & -12.2 & 11.3 \\
\hline
\end{tabular}

most likely breast cancer and brucellosis, while the third did not display any pathological changes, except $\mathrm{OA}$ on the metacarpals. As for the nitrogen, the mean value is slightly higher than in POB MON $1\left(\delta^{15} \mathrm{~N}=11.9 \% \circ \pm 0.8\right.$, from 10.4 to $13.0 \%$ ).

\section{Discussion}

\section{Animal diet}

The terrestrial animals' ${ }^{13} \mathrm{C}$ ranged from -18.7 to $-21.0 \%$, suggesting a low or null intake of $\mathrm{C}_{4}$ plants. Their $\delta^{15} \mathrm{~N}$ values showed moderate variability (6.6 to $9.9 \%$ ) reflecting different feeding types. The sheep's $\delta^{15} \mathrm{~N}$ values ranged from 6.6 to 9.6\% . According to their epiphyseal degree of fusion, all were prime adults and should not show any correspondence to the isotopic signal of their suckling stage. In fact, no correlation has been found between sheep size and isotopic values. The variability in the isotopic signatures of the sheep may indicate that they came from outside the convent yard, and possibly from various ecosystems or management systems (see, for example, López-Costas and Müldner 2016). Gallus also showed a variation in $\delta^{15} \mathrm{~N}(7.8$ to $9.4 \%$ ), their mean values being slightly higher than those of the sheep. Here, the observed variability could be caused by the different types of feed consumed by the hens (such as grain and feed leftovers) or even by their different vital stages (such as breeders or layers). They show no appreciable traces of $\mathrm{C}_{4}$ grain consumption $\left(\delta^{13} \mathrm{C}\right.$ from -19.9 to $-19.3 \%$ ) , as in other Iberian deposits (Alexander et al. 2015; Quirós Castillo 2013). The pigs, both domestic and wild, showed intermediate nitrogen 
signatures between the other terrestrial animals and the humans, reflecting their omnivore style of feeding that can include plant stuffs, small vertebrates for wild pigs, or human garbage, in the case of the domestic pig.

The only fish analysed, a catshark, showed a clear marine signature, similar to values published for samples taken from the Atlantic (López-Costas and Müldner 2016) or Mediterranean Iberian coasts (Alexander et al. 2015).

The fauna included in this study correspond to those of any time between the opening of the convent in the sixteenth century and its abandonment in the mid-twentieth century, although they probably date back to the earliest period, given that they were recovered from a certain depth. Throughout these centuries, the global climate suffered ups and downs, with differences in temperature and precipitation that could have altered the isotopic values of soils and plants; however, we do have data on variations in temperature and rainfall. For example, temperature reconstruction has been done for this period based on tree ring records from the nearby Iberian Range (Tejedor et al. 2017), where the authors suggest fluctuations in maximum temperatures of short duration (a few tens of years) of up to $3{ }^{\circ} \mathrm{C}$. For the same period, the tree rings also record dry, wet, and irregular rainfall (Ruiz-Labourdette et al. 2014).

It is difficult to quantify the effect that this climatic variation may have had on the isotopic values of the plants on which animal and human food was based, but in any case, there is no clear trend in temperature or precipitation, but rather a series of short-term fluctuations which, together with the resilience of the soil, could have minimised isotopic variation over the period studied.

\section{Nuns' dietary reconstruction}

Isotopic analyses of 49 individuals from POB MON 1 and 9 from POB MON 2, together with 13 faunal specimens, revealed that the female monastic population of the Convent of Santa Catalina de Siena had quite a homogeneous diet in general, with the exception of up to 4 individuals who present very different isotopic signatures, and whose cases will be discussed later on.

Considering the mean values of $\delta^{15} \mathrm{~N}$ of sheep as a baseline, the enrichment in ${ }^{15} \mathrm{~N}$ of POB MON 1 is relatively small $\left(\Delta^{15} \mathrm{~N}=3.2 \%\right.$ ) , and even smaller, compared to all domestic animals $\left(\Delta^{15} \mathrm{~N}=3.0 \%\right.$ o). This enrichment does not reach the lower limit of the generally accepted range for a trophic level, of between 3.5 and 5\%o (Bocherens and Drucker 2003) and is also lower than that proposed specifically for humans, of between 4 and 6\%o (O'Connell et al. 2012). This value indicates a low consumption of animal proteins, at least those of terrestrial origin, as can be observed in other populations of the Iberian Peninsula. For example, the isotopic study of several communities of the late medieval Basque Country (in the north of Spain) showed different levels of enrichment in domestic ungulates (cattle, sheep, goats, and pigs) and fowl. In the fortified village of Treviño, where high-class inhabitants lived, the offset is around $4.5 \%$, whereas in the rural community of Zornoztegui, the figure is around 2.6\%o (Lubritto et al. 2017).

Thus, the $\delta^{13} \mathrm{C}$ and $\delta^{15} \mathrm{~N}$ values in POB MON 1 are characteristic of a mainly terrestrial diet, rich in $\mathrm{C}_{3}$ vegetables, probably with a discrete input of marine resources. Despite the inland location of the site, several marine fish bones were recovered from the waste pits, showing that fish was a part of the nuns' diet, probably during fasting periods. Although the diet seems to be based on $\mathrm{C}_{3}$ plants, the direct and indirect consumption of $\mathrm{C}_{4}$ plants cannot be ruled out. From the baseline obtained from the obligated herbivores such as sheep, we can conclude that the nuns' diet was poor in food of animal origin, according to the restrictions imposed by their monastic order's rules.

\section{Changes in diet over time}

Excluding three individuals with markedly more positive $\delta^{13} \mathrm{C}$, the isotopic values of nineteenth- to twentieth-century nuns were very similar to those of the sixteenth- to seventeenth-century nuns, suggesting that the diet in the convent did not change over time. However, a comparison of carbon isotopic values between POB MON 1 and POB MON 2 cannot be done straightforwardly. The isotopic signature of atmospheric $\mathrm{CO}_{2}$ was not constant, but has rather varied significantly over the last 300 years due to the increased use of fossil fuels, the so-called Suess effect (Long et al. 2005). In this way, the average values of $\delta^{13} \mathrm{C}$ in the atmosphere during the sixteenth and seventeenth centuries were around $-6.5 \%$, while at present, they are slightly above $8 \%$. To compare the data from both necropolises, it would be necessary to use a corrective factor that minimises this baseline difference for $\delta^{13} \mathrm{C}$. However, we do not know the exact date of the burials for the POB MON 2 complex, except that they ranged from 1850 to 1925 . At that time, the $\delta^{13} \mathrm{C}$ values of atmospheric $\mathrm{CO}_{2}$ could have been up to $0.6 \%$ omore positive than in the sixteenth and seventeenth centuries (Friedli et al. 1986; Francey et al. 1999). For this reason, it should be borne in mind that some of the isotopic signatures obtained for POB MON 2 could be equivalent to values up to $0.6 \%$ more positive, if we compare them to the results of POB MON 1.

In addition, the six individuals present an average $\delta^{15} \mathrm{~N}$ value slightly higher than the mean value of POB MON 1, while the difference of the median is statistically significant (MannWhitney $U$ test, $p=0.0263$ ). This may indicate some increase over time of animal proteins in the diet of the Belmonte nuns. However, the data from POB MON 2 are very limited and it is therefore not appropriate to generalise the results; it would be necessary to include more individuals in the study to see 
Fig. 3 Bone collagen isotopic values of $\mathrm{POB}$ MON 1

individuals according to their age, sex, the presence of bone pathology, and their position in the tomb. For colour references, please refer to the online version of the article

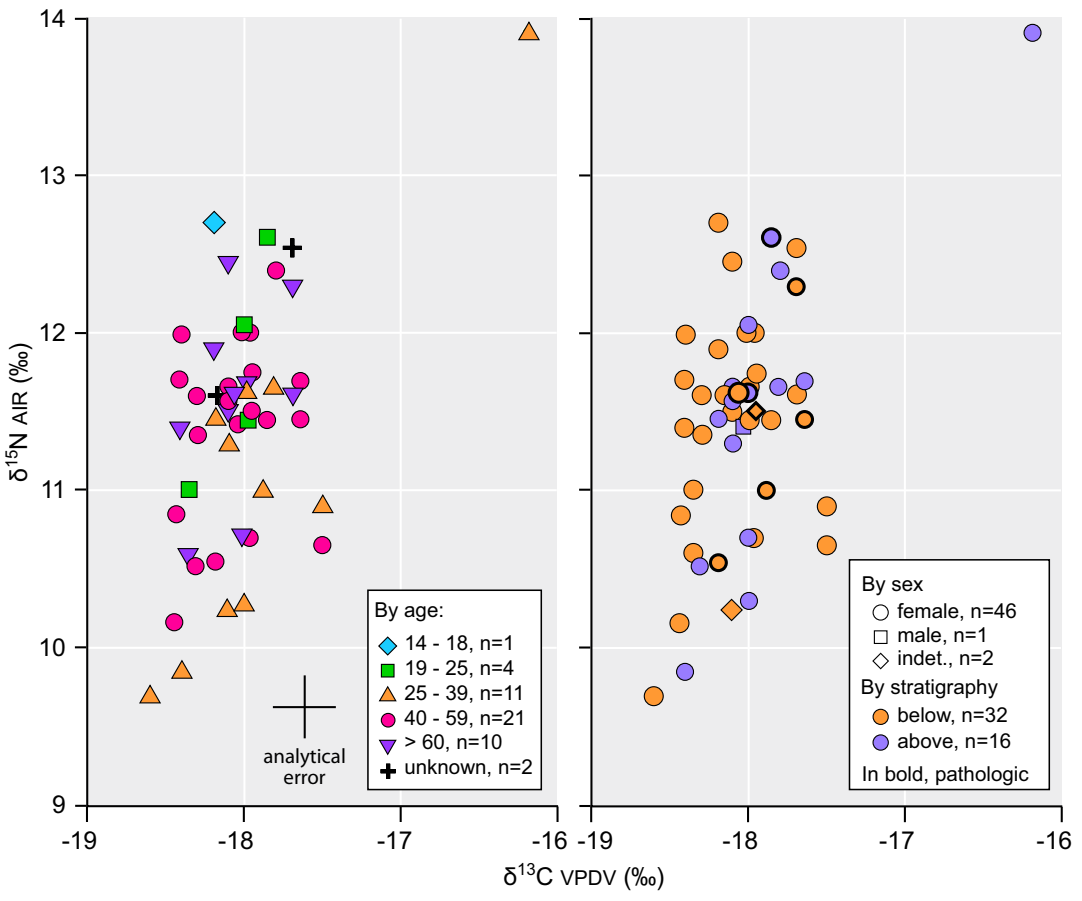

whether there was a shift to a diet richer in animal protein in the Belmonte community. Another problem to studying possible changes in the diet of the nuns over time is the lack of knowledge of the exact chronology of the animal remains used as an isotopic baseline. This problem is difficult to solve because the

Table 6 Results of statistic test (Kruskal-Wallis $H$ test with Bonferroni correction for all age groups and Mann-Whitney $U$ test with Monte Carlo permutation for paired age groups, health condition, and stratigraphy) for POB MON 1 individuals (excluding the outlier individual 12-24). For comparison in age classes, only classes with a number of individuals equal to or greater than 10 are included. The asterisks mark the significant differences, $(*)$ for $\alpha=0.05$ (two-tailed), $(* *)$ for $\alpha=0.10$ (two-tailed)

n $\quad \delta^{13} \mathrm{C} \quad \delta^{15} \mathrm{~N}$

By age:

$\begin{array}{ll}25-39 & 10 \quad H=0.0717, p=0.964 \quad H=6.019, p=0.0483 * \\ 40-59 & 21 \\ >60 & 10\end{array}$

By age (paired):

25-39 vs 40-59

$U=55.5, p=0.0345^{*}$

$25-39$ vs $>60$

$U=21.0, p=0.0269^{*}$

$40-59$ vs $>60$

$U=90.5, p=0.5524$

By health condition:

With pathologies $8 \quad U=93.5, p=0.0634^{* *} \quad U=142.5, p=0.6294$

No pathologies $\quad 40$

By stratigraphy:

$\begin{array}{ll}\text { Below } & 32\end{array} \quad U=204.5, p=0.2579 \quad U=249, p=0.8825$

animal remains came from stratigraphic units far from the nuns' tombs. The baseline for $\delta^{15} \mathrm{~N}$ may change slightly if there were significant changes in rainfall and temperature between the two time periods studied (Goude and Fontugne 2016); for $\delta^{13} \mathrm{C}$, the Suess effect could also be a source of variation. To solve the problem of finding a suitable isotopic baseline for any period of time, it would be necessary to conduct more studies of other human and animal groups in the region.

\section{Intrapopulation variability in $\delta^{15} \mathrm{~N}$}

Deniro and Schoeniger (1983) showed that isotopic variation in mesomammals raised on a monotonous diet, within either individuals or populations, is less than $1 \%$ o for both isotopes. Recent research in marine mammals (Clark et al. 2017) has yielded similar results. Based on the most numerous and best isotopically characterised POB MON 1 group alone, we observed that individuals revealed $\delta^{13} \mathrm{C}$ values within a limited range, from -17.6 to $-18.6 \%$. However, there is a moderate intrapopulation variability in $\delta^{15} \mathrm{~N}$, showing a shift of between 9.7 and $12.7 \%$. Such a range seems high for a community with a uniform diet, and this variability can be explained in various ways. First of all, it is possible that the nuns' diet was not as uniform as we assume, and that there were some differences in the proportion of food of animal origin. According to monastic rules, the sick had the right to refrain from fasting and eat meat during their period of illness, but when they recovered, they had to return to their habitual restrictions ("Constitutions of the Nuns of the Order of Preachers" 2015). However, the observed differences in $\delta^{15} \mathrm{~N}$ are not 
related to skeletal health conditions or stratigraphic levels, and only slightly vary with age, with the nuns aged between 25 and 39 years old showing lower $\delta^{15} \mathrm{~N}$ values. It is difficult to find a specific reason why there were these dietary differences in a community with such an austere life.

Secondly, it is possible that the restriction of animal protein in this diet caused an increase in the reuse of body N, with a consequent increase in $\delta^{15} \mathrm{~N}$ values, as described in the literature (Katzenberg and Lovell 1999; Fuller et al. 2005). Perhaps the differences observed do not reflect large variations in protein intake, but rather the effect of a negative nitrogen balance, whether involuntary or related to different levels of commitment regarding fasting. Finally, another possibility is that with the same type of diet, physiological differences such as the basal metabolic rate could produce a variation in $\delta^{15} \mathrm{~N}$ of this magnitude. It should be noted that the potential male individual revealed values similar to the average females' values for both $\delta^{13} \mathrm{C}$ and $\delta^{15} \mathrm{~N}$.

The highest $\delta^{15} \mathrm{~N}$ value in POB MON 1, except the outlier 12-24, was for the individual 9-22, who was only 14-18 years old at the time of her death. We could conclude that due to her young age, she was excluded from the dietary restrictions that applied to the rest of the community.

\section{Belmonte's outliers}

There was only one outlier in POB MON 1: an individual marked 12-24, aged 25-39, who presented $\delta^{13} \mathrm{C}$ and $\delta^{15} \mathrm{~N}$ values much higher than the rest of the population, which can be associated with either a large contribution of marine resources, or animal protein fed with $\mathrm{C}_{4}$ plants. In any case, it seems that this individual had a diet markedly different to that of the rest of the community. One likely explanation for this is that the woman joined the convent not long before her death, having previously maintained a diet richer in meat and fish than that of the other nuns, or that she was not a nun but a convent guest, probably from a high social class, as it was a case for elites buried in Seville cathedral (Jiménez-Brobeil et al. 2016). A person whose diet was richer in food of animal origin had no visible pathological changes, except for slight osteoarthrosis. Historical accounts inform us about one case from this convent in the nineteenth century, when money for the repairing of the oven was obtained by a monastic dowry of 600 ducats "given by a lady of the court who had retired to the convent" (Caballero and Sánchez 2013); this shows that such a practice existed, so this may be the same case with the individual 12-24 in earlier times.

In POB MON 2, six of the nine individuals recorded isotope values that fall into the variability of the earlier population, if the above-mentioned correction for $\delta^{13} \mathrm{C}$ values is taken into account. This points to a similar diet over time for the community. The other three individuals, according to their combination of high $\delta^{13} \mathrm{C}$ and low $\delta^{15} \mathrm{~N}$ values, had a diet that contained more $\mathrm{C}_{4}$ plants, probably corn and/or sugar.
It is possible that these individuals followed a particular diet entirely different from that of the other nuns for some unknown reasons. Two of them were chronically sick, presenting pathological changes that are in accordance with brucellosis and breast cancer, but the third individual did not have any pathological changes visible on her skeleton except for dental diseases, although it is possible that she suffered from a disease that did not leave pathological traces on the bones. The use of corn in traditional medicine is well known (Honda et al. 1996; González-Hernádez et al. 2002; Vallejo and González 2013), but it is not clear if that could be the reason for the higher $\mathrm{C}_{4}$ values. Another possibility is that due to their health conditions or some other reasons, those individuals had a special, more maize-based diet. Although corn had been known since Columbus' voyage and the "discovery" of America (late fifteenth century), there was no sign of its usage in POB MON 1, neither in the archaeological excavations nor in the $\delta^{13} \mathrm{C}$ isotopic signature. Historical sources explain that occurrence by the contention that until the eighteenth century, corn was food for poor humans and animals, but after periods of famine, it became used by all social classes (Azcoytia 2009). The change in the $\delta^{13} \mathrm{C}$ signal could also be a consequence of higher consumption of sugar. Although sugar cane has been known in Europe since the time of the Romans and Greeks, it was considered a luxury foodstuff until the eighteenth century, when it became more affordable, and in the nineteenth century it came to be considered a necessity (Wright 1986). Controlled feeding studies have demonstrated that collagen $\delta^{13} \mathrm{C}$ preferentially reflects dietary protein, while bone carbonate $\delta^{13} \mathrm{C}$ reveals energy components (Lee-Thorp 2008). However, it has also been observed that in diets with low protein content, carbohydrates contributed to $\delta^{13} \mathrm{C}$ in the body protein of the consumer (Ambrose and Norr 1993), probably due to cataplerotic reactions - that is, the routing of glycolysis and citric acid cycle intermediates to produce amino acids (Owen et al. 2002). In a protein-restricted diet, if a major source of energy comes from sugar cane $\left(\mathrm{C}_{4}\right.$ plant), it can be expected that bone collagen records that contribution with more positive values than in individuals with a normal diet or a diet poor in sugar.

The hypothesis of a higher consumption of sugar in $\mathrm{POB}$ MON 2 is supported by the statistically significant frequency of caries $(p=0.003)$, given that studies have confirmed the direct relationship between the intake of dietary sugars and dental caries (Burt and Pai 2001; Touger-Decker and Van Loveren 2003). The individuals who showed different isotopic signals in comparison to other nuns from POB MON 2 also had a high frequency of caries. A total of $22 \%$ of the preserved teeth from individual 21 were affected with caries, for individual 24 the figure was $19 \%$, and $64.7 \%$ for individual 28A. However, the $\delta^{15} \mathrm{~N}$ values of these three nuns (mean value $11.4 \% \circ \pm 0.3$ ) matched the mean values of the convent 
population, and show an offset over domestic fauna of + $3.0 \%$, indicating that they did not experience especial protein restriction - or at least not more than their counterparts.

It is also possible that these three individuals were recent migrants from another location, where they had followed a radically different diet in the last years of their lives.

\section{Isotope signatures and pathology}

Pathological changes that can be connected to malnutrition such as scurvy were not recorded in these two female monastic populations; neither was DISH, which is commonly associated with obesity and diabetes (among other causes) and has frequently been found in male monastic populations in the past (Rogers and Waldron 2001). Although there was one case of osteomalacia, in the context of the monastic population, the lack of vitamin $\mathrm{D}$ can be more easily attributed to the lack of sunlight (enclosure, thick clothes that cover almost the entire body) than to dietary deficiencies. Of the porotic lesions in the populations, only femoral cribra was relatively frequent (32.1\% in POB MON 1 and 22\% in POB MON 2), while others (humeral cribra, cribra orbitalia, and porotic hyperostosis) were not common (Sarkic 2017). In contrast, more than half of the secular population from the nineteenth century in Belmonte showed signs of porotic hyperostosis, and even one case of chronic malnutrition, manifested by signs of scurvy (Sarkic 2017). This could lead us to the conclusion that the nuns had a more balanced diet than the secular population.

\section{Comparison between Belmonte nuns' diet and the secular population}

It was not possible to include the secular population buried in the convent of Belmonte in this work, which would have been the best way to find out if the monastic diet was very different from that of the lay people. It is difficult to know this for sure, based on the existing data, since there is a lack of isotopic studies in human groups from the same period and geographical area. Some studies refer to early medieval Muslim populations such as that of Tauste (Zaragoza), situated like Belmonte in the interior of the Peninsula (Guede et al. 2017), or that of Tossal de les Basses, on the Mediterranean coast (Salazar-García et al. 2016), but it does not seem appropriate to compare Muslim populations, who had particular dietary characteristics, with Christian nuns of a later period. The closest data in time and space come from the coastal town of Gandía, located about $150 \mathrm{~km}$ from Belmonte. There, the study of late medieval-early modern (the eleventh to the sixteenth century) mudéjar (Muslim) and Christian necropolises (Alexander et al. 2015) has revealed lower $\delta^{15} \mathrm{~N}$ absolute values, yet they are enriched around $+6 \%$ over local ovicaprids (that show unusually low $\delta^{15} \mathrm{~N}$ values), and whose suggested diet included different proportions of fish and $\mathrm{C}_{4}$ plants intake (Fig. 4); although fish is more apparent in the Muslim community, with mean $\delta^{13} \mathrm{C}=16.4 \pm 0.9 \%$ o than for the Christians $\left(\delta^{13} \mathrm{C}=-18.3 \pm 0.3 \%\right.$, only $1.0 \%$ more positive than for sheep). In contrast, Belmonte individuals show a much lower $\delta^{15} \mathrm{~N}$ offset $\left(+3.2 \%\right.$ ) but higher $\delta^{13} \mathrm{C}(+1.7 \%$ o $)$ compared to sheep, than the Gandía Christians.

\section{Comparison with other monastic communities}

There are few isotope studies of other monastic communities, and none in Spain. In addition, most, if not all, of the published isotopic studies concern male monastic or religious communities. The analysis of the Capela do Pilar collection, found inside Lugo cathedral (in northwest Spain), revealed isotopic signatures highly enriched in ${ }^{15} \mathrm{~N}$ for male adults (López-Costas 2012). The osteoarchaeological and historical study suggested that these individuals might have belonged to

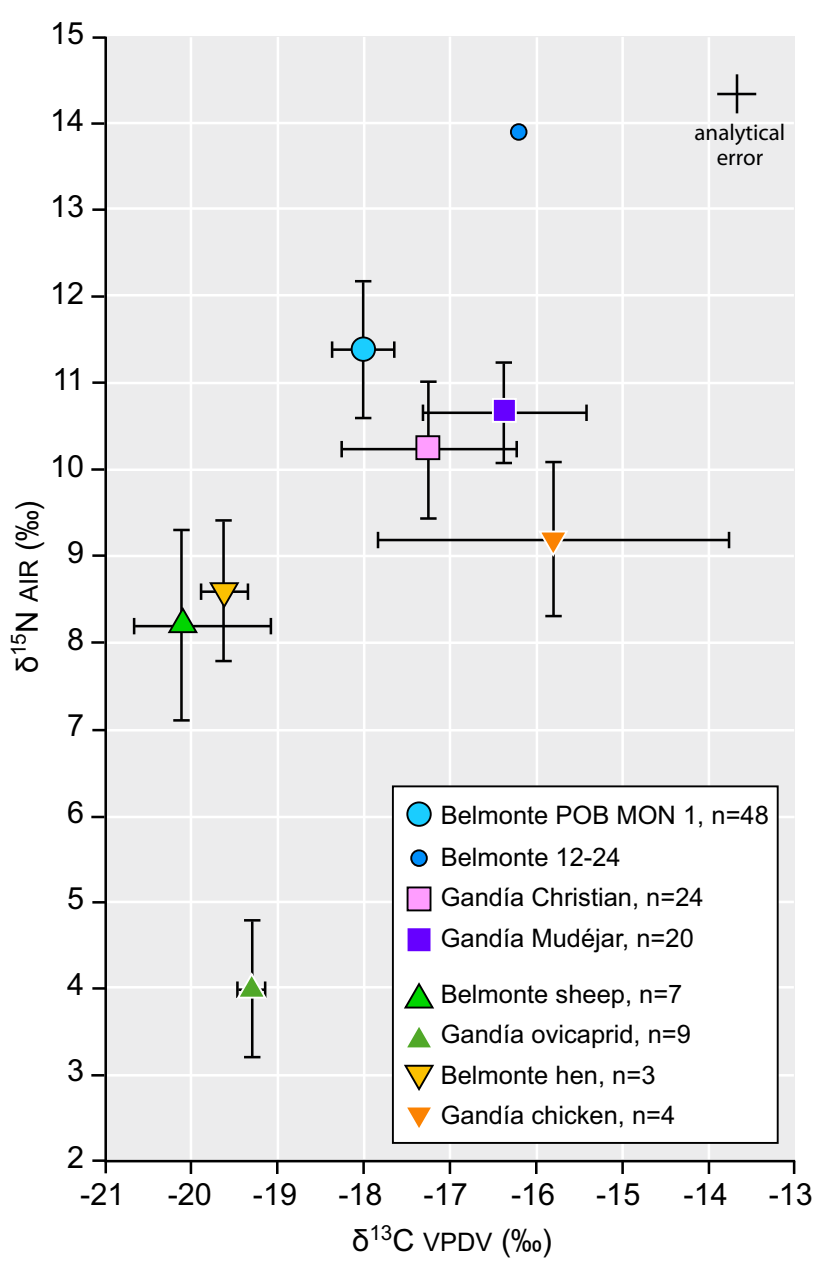

Fig. 4 The comparison of the isotopic values (mean $\pm 1 \sigma$ ) of the Belmonte necropolis POB MON 1 with those of the nearby coastal Late Medieval town of Gandía (Alexander et al. 2013). In the latter, two populations of different religions show isotope signatures compatible with a diet that includes $\mathrm{C}_{4}$ vegetables and fish in different proportions. Ovicaprids and chicken are also shown for baseline information 
the cathedral's noble clergy stratum (bishops and chaplains); a high consumption of animal proteins and a notable presence of fish has been found in these cases, in comparison to contemporary inland populations.

In the Byzantine monastery of St. Stephen in Jerusalem, low values of $\delta^{15} \mathrm{~N}$ (mean 9.6\% \pm 1.17 ) were recorded, only $2.4 \%$ higher than that of coeval domestic herbivores (Gregoricka and Guise Sheridan 2013), but some individuals with higher $\delta^{15} \mathrm{~N}$ values compared to the animal baseline were interpreted as consuming more animal protein than other monks, although the monastic rules restricted the consumption of this type of food, which was also scarce and expensive. Another possibility suggested by the authors is that these individuals were foreign. Although both sets of data cannot be compared in absolute values due to their geographical and chronological differences, a greater dispersion in the isotopic values of St. Stephen than that of Belmonte (SD in St. Stephen $=1.2$, SD in POB MON 1 excluding the outlier $=$ 0.962 ) is clearly visible in the $95 \%$ concentration ellipse graph (Fig. 5).

Quintelier et al. (2014) studied a post-medieval male Carmelite community in Aalst, Belgium. The inhumations from three locations in the monastery correspond to friars and the wealthy lay population, although there is no clear separation between the two groups. They conclude that although the friars' diet included more fish than the meat-rich, secular diet, both groups are isotopically indistinguishable. In Aalst, male individuals, whether friars or laymen, showed a diet richer in animal protein than females. A wide range of stable human isotope ratios suggests an extent of dietary diversity in Aalst, including meat and freshwater and marine fish in different proportions. The isotopic offset between domestic fauna and humans is around 5\%o (Quintelier et al. 2014).

As mentioned previously, in Belmonte, we observed a possible increase in animal protein intake between POB MON 1 and POB MON 2. Something similar was observed in the Dominican monastery of Rennes (Brittany), where earlymodern age monks $(n=6)$ manifested a diet similar to that of the privileged class, unlike medieval monks $(n=3)$, whose diet was poorer, and similar to the secular population buried outside the convent (Colleter et al. 2017). Even so, the difference in POB MON 2 with respect to POB MON $1\left(\Delta^{15} \mathrm{~N}=\right.$ $0.5 \%$ ) is much smaller than that presented by the monks of Rennes $\left(\Delta^{15} \mathrm{~N}=1.4 \%\right)$. However, both the data from POB MON 2 and the monastery in Rennes are limited, so it is risky to generalise any conclusions.

\section{Conclusions}

In this work, we carried out an isotopic characterisation of a monastic female population who followed a very restricted

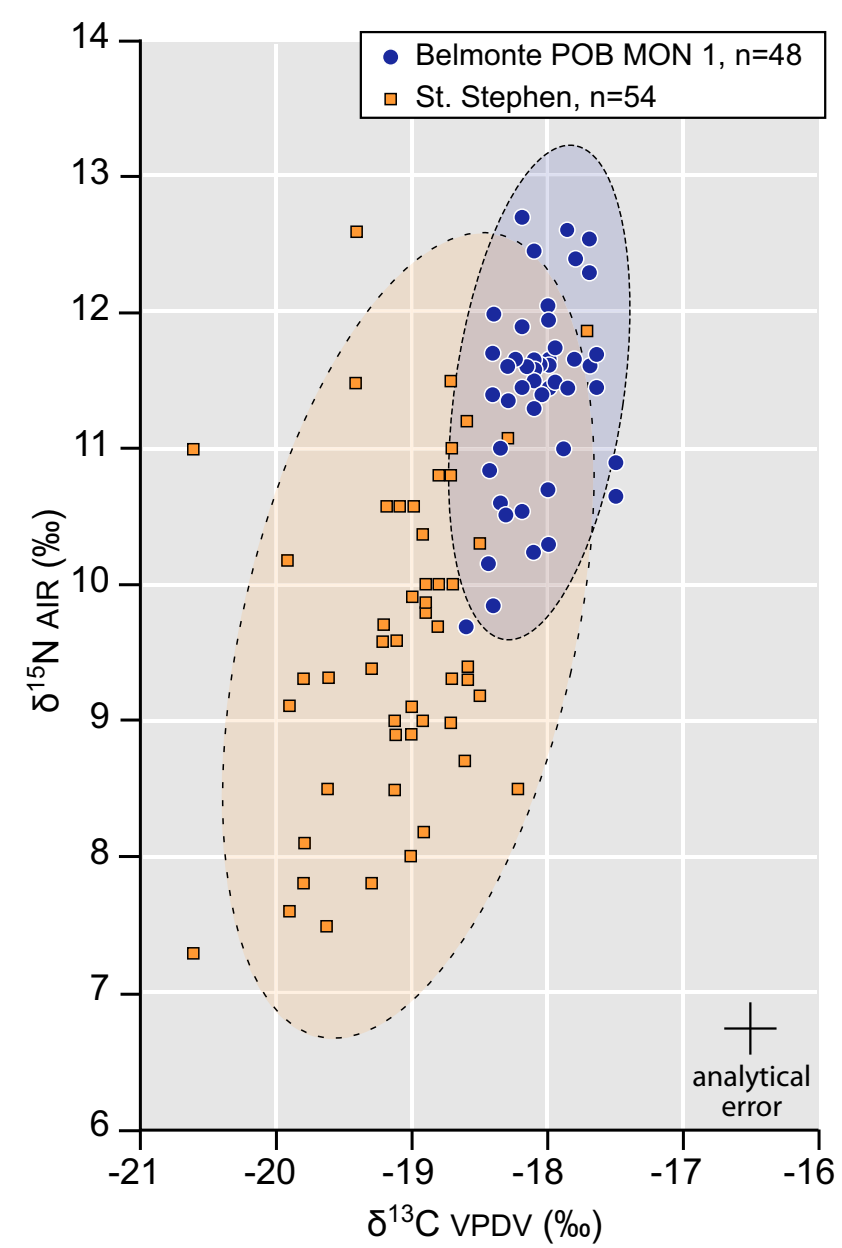

Fig. 5 The comparison of isotopic values of the sixteenth to seventeenth century Belmonte necropolis (POB MON 1) excluding the outlier and the Byzantine monastery of St. Stephen in Jerusalem (Gregoricka and Guise 2013). Concentration ellipses represent a $95 \%$ probability of finding a new sample of the same group within the surface defined by the ellipse

diet, as imposed by the rules of their order. It seems that the religious restrictions on the consumption of meat and terrestrial animal products during approximately half of each year did not have a negative impact that can be observed on the bones of the nuns.

Isotopic analyses show that the nuns practised an austere life with a uniform diet, that remained the same over the centuries, and very small isotopic differences in relation to the age of individuals or pathologies they have. The diet was mostly based on $\mathrm{C}_{3}$ vegetables, but with some inputs of marine fish, in agreement with the historical records. The intrapopulation variation in $\delta^{15} \mathrm{~N}$ suggests that the nuns, while maintaining a high commitment to fasting imposed by their rule (as opposed to male monastic communities), could have had some flexibility in their consumption of animal proteins. It is also possible that these differences may have resulted from a combination of physiological mechanisms (such as growth, the bone-remodelling rate, and reminiscences of their previous diet), even with a totally uniform diet. 
The same diet was followed by one possibly male individual. However, there were some exceptions to general homogeneity: an individual who was probably not part of the religious community, and who had a diet more abundant in meat and fish, and three individuals with isotopic signatures distinctly oriented towards $\mathrm{C}_{4}$ vegetables, probably due to their relocation to this convent in the last years of their lives.

Acknowledgements Photos from the excavation of the monastery have been provided by courtesy of Rafael Caballero García.

Funding information The isotopic study was carried out with funding from the CONSILIENCIA network (R2014/001; ED 431D2017/08) of the Consolidation and Structuring Programme of Research Units of the Xunta de Galicia, and a consolidating grant of the Xunta de Galicia for emerging research groups to the group CULXEO (GPC2015/024). OLC is funded by Plan Galego I2C mod.B (ED481D 2017/014).

Open Access This article is distributed under the terms of the Creative Commons Attribution 4.0 International License (http:// creativecommons.org/licenses/by/4.0/), which permits unrestricted use, distribution, and reproduction in any medium, provided you give appropriate credit to the original author(s) and the source, provide a link to the Creative Commons license, and indicate if changes were made.

Publisher's Note Springer Nature remains neutral with regard to jurisdictional claims in published maps and institutional affiliations.

\section{References}

Acsádi G, Nemeskéri J (1970) History of human life span and mortality. Akadémiai Kiadó, Budapest

Alexander MM, Gerrard CM, Gutiérrez A, Millard AR (2015) Diet, society, and economy in late medieval Spain: stable isotope evidence from Muslims and Christians from Gandía, Valencia. Am J Phys Anthropol 156(2):263-273

Alperi V, Fernandez S (2012) La Cocina de los Conventos. Ediciones Nobel, Oviedo

Ambrose SH (1990) Preparation and characterization of bone and tooth collagen for stable carbon and nitrogen isotope analysis. J Archaeol Sci 17:431-451

Ambrose SH, Norr L (1993) Experimental evidence for the relationship of the carbon isotope ratios of whole diet and dietary protein to those of bone collagen and carbonate. In: Lambert JB, Grupe G (eds) Prehistoric human bone: archaeology at the molecular level. Springer-Verlag, Berlin, pp 1-37

Azcoytia C (2009) Historia del maíz en España y la pelagra o el mal de la rosa. Historia de la Cocina y la Gastronomía. https://www. historiacocina.com/es/maiz-espana. Accessed 18 March 2018

Bamji A (2016) The catholic life cycle. In: Bamji A, Janssen GH, Laven $M$ (eds) The Ashgate research companion to the CounterReformation. Routledge, New York, pp 183-201

Beaumont J, Montgomery J, Buckberry J, Jay M (2015) Infant mortality and isotopic complexity: new approaches to stress, maternal health, and weaning. Am J Phys Anthropol 157(3):441-157

Bocherens H, Drucker D (2003) Trophic level isotopic enrichment of carbon and nitrogen in bone collagen: case studies from recent and ancient terrestrial ecosystems. Int J Osteoarchaeol 13(1-2):46-53

Bocherens H, Billiou D, Patou-Mathis M, Bonjean D, Otte M, Mariotti A (1997) Palaeobiological implications of the isotopic signatures
$(13 \mathrm{C}, 15 \mathrm{~N})$ of fossil mammal collagen in Scladina Cave (Sclayn, Belgium). Quat Res 48:370-380

Bocherens H, Drucker D, Billiou D, Moussa I (2005) Une nouvelle approche pour évaluer l'état de conservation de l'os et du collagène pour les mesures isotopiques (datation au radiocarbone, isotopes stables du carbone et de l'azote). L'Anthropologie 109: $557-567$

Bonsall C, Lennon R, McSweeney K, Stewart C, Harkness D, Boroneanț V, Payton R, Bartosiewicz L, Chapman JC (1997) Mesolithic and Early Neolithic in the Iron Gates: a palaeodietary perspective. J Eur Archaeol 5(1):50-92

Bownes J, Clarke L, Buckberry J (2018) The importance of animal baselines: using isotope analysis to compare diet in a British medieval hospital and lay population. J Archaeol Sci Rep 17:103-110

Bruzek J (2002) A method for visual determination of sex, using the human hip bone. Am J Phys Anthropol 117(2):157-168

Buikstra JE, Mielke JL (1985) Demography, diet, and health. In: Gilbert RI, Mielke JH (eds) Analysis of prehistoric diets. Academic Press, Orlando, pp 360-422

Buikstra JE, Ubelaker DH (1994) Standards for data collection from human skeletal remains: proceedings of a seminar at the Field Museum of Natural History. Arkansas Archeological Survey, Fayetteville

Burt BA, Pai S (2001) Sugar consumption and caries risk: a systematic review. J Dent Educ 65(10):1017-1023

Caballero R, Sánchez E (2013) Intervención arqueológica en el antiguo Alcázar del infante D. Juan Manuel. Término municipal: Belmonte (Cuneca). Memoria final de la actuación arqueológica

Casey MM, Post DM (2011) The problem of isotopic baseline: reconstructing the diet and trophic position of fossil animals. Earth-Sci Rev 106:131-148

Chisholm BS, Nelson DE, Schwarcz HP (2006) Stable carbon isotope ratios as a measure of marine versus terrestrial protein in ancient diets. Science 216:1131-1132

Clark CT, Horstmann L, Misarti N (2017) Quantifying variability in stable carbon and nitrogen isotope ratios within the skeletons of marine mammals of the suborder Caniformia. J Archaeol Sci Rep 15:393400

Colleter R, Clavel B, Pietrzak A, Duchesne S, Schmitt L, Richards MP, Telmon N, Crubézy, E, Jaouen K (2017) Social status in late medieval and early modern Brittany: insights from stable isotope analysis. Archaeol Anthropol Sci

"Constitutions of the Nuns of the Order of Preachers" (2015) Retrieved from http://www.op.org/sites/www.op.org/files/public/documents/ fichier/nuns constitutions 020311.pdf

De Maeyer J, Leplae S, Schmiedl J (2004) Religious Institutes in Western Europe in the 19th and 20th Centuries: Historiography, Research and Legal Position (Vol. 2). Leuven University Press, Leuven

Deniro MJ (1985) Post-mortem preservation and alteration of in vivo bone collagen isotope ratios in relation to paleodietary reconstruction. Nature 317:806-809

Deniro MJ (1987) Stable isotopy and archaeology. Am Sci 75(2):182191

Deniro MJ, Epstein S (1981) Influence of diet on the distribution of nitrogen isotopes in animals. Geochim et Cosmochim Acta 45(3): 341-351

Deniro MJ, Schoeniger MJ (1983) Stable carbon and nitrogen isotope ratios of bone collagen: variations within individuals, between sexes, and within populations raised on monotonous diets. J Archaeol Sci 10(3):199-203

Driver JC (1982) Medullary bone as an indicator of sex in bird remains from archaeological sites. In: Wilson B (ed) Ageing and sexing animal bones from archaeological sites. British Archaeological Reports 109, Oxford, pp 251-254

Fahy GE, Deter C, Pitfield R, Miszkiewicz JJ, Mahoney P (2017) Bone deep: variation in stable isotope ratios and histomorphometric 
measurements of bone remodelling within adult humans. J Archaeol Sci 87:10-16

Floristán A (2011) Historia moderna universal. Ariel, Barcelona

Francey RJ, Allison CE, Etheridge DM, Trudinger CM, Enting IG, Leuenberger M, Langenfelds RL, Michel E, Steele LP (1999) A 1000 -year high precision record of $813 \mathrm{C}$ in atmospheric $\mathrm{CO} 2$. Tellus B51(2):170-193

Friedli H, Lötscher H, Oeschger H, Siegenthaler U, Stauffer B (1986) Ice core record of the $13 \mathrm{C} / 12 \mathrm{C}$ ratio of atmospheric $\mathrm{CO} 2$ in the past two centuries. Nature 324(6094):237-238

Fuller BT, Fuller JL, Sage NE, Harris DA, O'Connell TC, Hedges REM (2005) Nitrogen balance and delta ${ }^{15} \mathrm{~N}$ : why you're not what you eat during nutritional stress. Rapid Commun Mass Spectrom 19(18): $2497-2506$

González-Hernádez MP, Romero R, Rodríguez-Guitián M, Rigueiro A (2002) Medicinal use of some plants in Galicia (NW Spain). XXVI International Horticultural Congress: the Future for Medicinal and Aromatic Plants 629:63-75

Goude G, Fontugne M (2016) Carbon and nitrogen isotopic variability in bone collagen during the Neolithic period: influence of environmental factors and diet. J Archaeol Sci 70:117-131

Gregoricka LA, Guise Sheridan S (2013) Ascetic or affluent? Byzantine diet at the monastic community of St. Stephen's, Jerusalem from stable carbon and nitrogen isotopes. J Anthropol Archaeol 32:63-73

Grubbs FE (1969) Procedures for detecting outlying observations in samples. Technometrics 11(1):1-21

Guede I, Ortega LA, Zuluaga MC, Alonso-Olazabal A, Murelaga X, Pina M, Gutierrez FJ, Iacumin P (2017) Isotope analyses to explore diet and mobility in a medieval Muslim population at Tauste (NE Spain). PLoS One 12(5):e0176572. https://doi.org/10.1371/journal.pone. 0176572

Hammer Ø, Harper DAT, Ryan PD (2001) PAST: paleontological statistics software package for education and data analysis. Palaeontol Electron 4(1):9 http://palaeo-electronica.org/2001_1/past/issue1 01.htm. Accessed 13 May 2018

Hedges R, Reynard L (2007) Nitrogen isotopes and the trophic level of humans in archaeology. J Archaeol Sci 34:1240-1251

Honda G, Yeșilada E, Tabata M, Sezik E, Fujita T, Takeda Y, Takaishi Y, Tanaka T (1996) Traditional medicine in Turkey VI. Folk medicine in West Anatolia: Afyon, Kütahya, Denizli, Muğla, Aydin provinces. J Ethnopharmacol 53(2):75-87

Jiménez-Brobeil SA, Laffranchi Z, Maroto RM, López Sánchez FA, Delgado Huertas A (2016) How royals feasted in the court of Pedro I of Castile: A contribution of stable isotope study to medieval history. J Archaeol Sci Rep 10:424-430

Katzenberg MA, Lovell NC (1999) Stable isotope variation in pathological bone. Int J Osteoarchaeol 9:316-324

Larsen CS (2002) Bioarchaeology: the lives and lifestyles of past people. J Archaeol Res 10:119-166

Lee-Thorp J (2008) On isotopes and old bones. Archaeometry 50(6):925950

Libro Becerro del Monasterio de Nuestra Señora de la Mejorada, de La Orden de San Jerónimo, de la villa de Olmedo, Archive Dominican Convent of Olmedo, Fols. 5 and 6 [Manuscrit] (1760) Retrived from http://uvadoc.uva.es/handle/10324/416

Long ES, Sweitzer RA, Diefenbach DR, Ben-David M (2005) Controlling for anthropogenically induced atmospheric variation in stable carbon isotope studies. Oecologia 146:148-156

Longin R (1971) New method of collagen extraction for radiocarbon dating. Nature 230:241-242

López-Costas O (2012) Antropología de los restos óseos humanos de Galicia: Estudio de la población romana y medieval gallega. Doctoral thesis. Universidad de Granada

López-Costas O, Müldner G (2016) Fringes of the empire: Diet and cultural change at the Roman to post-Roman transition in NW Iberia. Am J Phys Anthropol 161(1):141-154
Loth SR, Henneberg M (1998) Mandibular ramus flexure is a good indicator of sexual dimorphism. Am J Phys Anthropol 105:91-92

Lubritto C, García-Collado MI, Ricci P, Altieri S, Sirignano C, Quirós Castillo JA (2017) New dietary evidence on medieval rural communities of the Basque Country (Spain) and its surroundings from carbon and nitrogen stable isotope analyses: social insights, diachronic changes and geographic comparison. Int J Osteoarchaeol 27:984-1002

Mays S (2006) Spondylolysis, spondylolisthesis, and lumbo-sacral morphology in a medieval English skeletal population. Am J Phys Anthropol 131(3):352-362

McCutchan JH Jr, Lewis WM Jr, Kendall C, McGrath CC (2003) Variation in trophic shift for stable isotope ratios of carbon, nitrogen, and sulfur. Oikos 102:378-390

Meindl RS, Lovejoy CO, Mensforth RP, Carlos LD (1985) Accuracy and direction of error in the sexing of the skeleton: implications for paleodemography. Am J Phys Anthropol 68(1):79-85

Milner GR (1992) Determination of skeletal age and sex: a manual prepared for the Dickson Mounds Reburial Team. Dickson Mounds Museum, Lewiston, Illinois

Müldner G, Richards MP (2005) Fast or feast: reconstructing diet in later medieval England by stable isotope analysis. J Archaeol Sci 32(1): $39-48$

Müldner G, Richards MP (2007) Diet and diversity at later medieval Fishergate: the isotopic evidence. Am J Phys Anthropol 134(2): $162-174$

Müldner G, Montgomery J, Cook G, Ellam R, Gledhill A, Lowe C (2009) Isotopes and individuals: diet and mobility among the medieval bishops of Whithorn. Antiquity 83(322):1119-1133

O'Connell TC, Kneale CJ, Tasevska N, Kuhnle GGC (2012) The dietbody offset in human nitrogen isotopic values: a controlled dietary study. Am J Phys Anthropol 149:426-434

Olsen KC, White CD, Longstaffe FJ, von Heyking K, McGlynn G, Grupe $\mathrm{G}$, Rühli FJ (2014) Intraskeletal isotopic compositions $\left(\delta^{13} \mathrm{C}, \delta^{15} \mathrm{~N}\right)$ of bone collagen: nonpathological and pathological variation. Am J Phys Anthropol 153:598-604

Ortner DJ (2003) Identification of pathological conditions in human skeletal remains. Academic Press, Cambridge

Owen OE, Kalhan SC, Hanson RW (2002) The key role of anaplerosis and cataplerosis for citric acid cycle function. J Biol Chem 277(34): 30409-30412

Phenice TW (1969) A newly developed visual method of sexing the os pubis. Am J Phys Anthropol 30(2):297-301

Polet C, Katzenberg MA (2003) Reconstruction of the diet in a mediaeval monastic community from the coast of Belgium. J Archaeol Sci 30(5):525-533

Quintelier K, Ervynck A, Müldner G, Neer W, Richards MP, Fuller BT (2014) Isotopic examination of links between diet, social differentiation, and DISH at the post-medieval Carmelite Friary of Aalst, Belgium. Am J Phys Anthropol 153(2):203-213

Quirós Castillo JA (2013) Los comportamientos alimentarios del campesinado medieval en el País Vasco y su entorno (siglos VIIIXIV). Historia Agraria 59:13-41

Reitsema LJ (2013) Beyond diet reconstruction: stable isotope applications to human physiology, health, and nutrition. Am J Hum Biol 25(4):445-456

Rey Castelao O (2009) Las instituciones monásticas femeninas, ¿centros de producción?. Manuscrits: revista d'història moderna. (27):59-76

Roberts CA, Manchester K (2005) The archaeology of disease. Cornell University Press, Ithaca

Rogers J, Waldron T (2001) DISH and the monastic way of life. Int J Osteoarchaeol 11(5):357-365

Ruiz-Labourdette D, Génova M, Schmitz MF, Urrutia R, Pineda FD (2014) Summer rainfall variability in European Mediterranean 
mountains from the sixteenth to the twentieth century reconstructed from tree rings. Int J Biometeorol 58(7):1627-1639

Salazar-García DC, Romero A, García-Borja P, Subirà ME, Richards MP (2016) A combinated dietary approach using isotope and dental bucal-microwear analysis of human remains from the Neolithic, Roman and Medieval periods from the archaeological site of Tossal de les Basses (Alicante, Spain). J Archaeol Sci Rep 6:610 619

Santonja JL (1999) La construcción de cementerios extramuros: Un aspecto de la lucha contra la mortalidad en el Antiguo Régimen. Revista de Historia Moderna 17:33-44

Sarkic N (2017) A study of the lifestyle and health parameters of nuns from convents on the Iberian Peninsula in modern times. Doctoral thesis. Autonomous University of Madrid

Schoeninger MJ, DeNiro MJ (1984) Nitrogen and carbon isotopic composition of bone collagen from marine and terrestrial animals. Geochim Cosmochim Acta 48:625-639

Schwarcz HP, Schoeninger MJ (2012) Stable isotopes of carbon and nitrogen as tracers for paleo-diet reconstruction. In: Baskaran M (ed) Handbook of environmental isotope geochemistry. Advances in Isotope Geochemistry, Springer, Berlin, pp 725-742

Tejedor E, Saz MÁ, Cuadrat JM, Esper J, De Luis M (2017) Temperature variability in the Iberian Range since 1602 inferred from tree-ring records. Clim Past 13:93-105

Touger-Decker R, Van Loveren C (2003) Sugars and dental caries. Am J Clin Nutr 78(4):881S-892S
Vallejo JR, González JA (2013) The use of the head louse as a remedy for jaundice in Spanish folk medicine: an overview. J Ethnobiol Ethnomed 9(1):52

Van der Merwe NJ (1982) Carbon isotopes, photosynthesis, and archaeology: Different pathways of photosynthesis cause characteristic changes in carbon isotope ratios that make possible the study of prehistoric human diets. Am Sci 70(6):596-606

Van Klinken GJ (1999) Bone collagen quality indicators for palaeodietary and radiocarbon measurements. J Archaeol Sci 26:687-695

Walker PL (2005) Greater sciatic notch morphology: Sex, age, and population differences. Am J Phys Anthropol 127(4):385-391

Walker PL, Bathurst RR, Richman R, Gjerdrum T, Andrushko VA (2009) The causes of porotic hyperostosis and cribra orbitalia: a reappraisal of the iron-deficiency anemia hypothesis. Am J Phys Anthropol 139:109-125

Wright WR (1986) Sweetness and power; the place of sugar in modern history. Science 232:111-112

Yoder C (2012) Let them eat cake? Status-based differences in diet in medieval Denmark. J Archaeol Sci 39(4):1183-1193

Zeder MA (2006) Reconciling rates of long bone fusion and tooth eruption and wear in sheep (Ovis) and goat (Capra). In: Ruscillo D (ed) Recent advances in ageing and sexing animal bones (9th ICAZ Conference, Durham 2002). Oxbow Books, Oxford, pp 87-118

Zeder M, Lapham HA (2010) Assessing the reliability of criteria used to identify post cranial bones in sheep, Ovis, and goats, Capra. J Archaeol Sci 37:2887-2905 